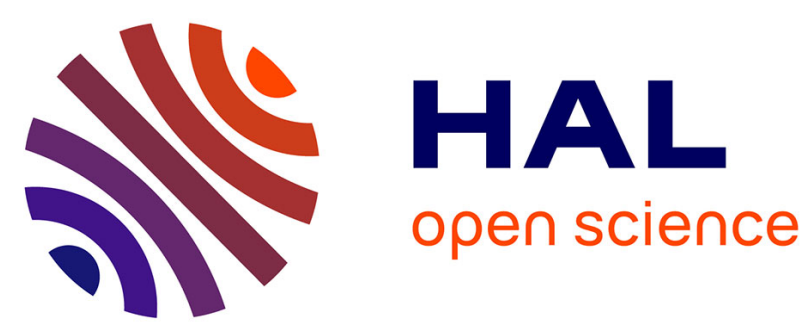

\title{
"Modern agriculture" transfers many pesticides to watercourses: a case study of a representative rural catchment of southern Brazil
}

José Augusto Monteiro de Castro Lima, Jérôme Labanowski, Marília Camotti Bastos, Renato Zanella, Osmar Damian Prestes, Jocelina Paranhos Rosa de Vargas, Leslie Mondamert, Eugenie Granado, Tales Tiecher, Mohsin Zafar, et al.

\section{- To cite this version:}

José Augusto Monteiro de Castro Lima, Jérôme Labanowski, Marília Camotti Bastos, Renato Zanella, Osmar Damian Prestes, et al.. "Modern agriculture" transfers many pesticides to watercourses: a case study of a representative rural catchment of southern Brazil. Environmental Science and Pollution Research, 2020, 27 (10), pp.10581-10598. 10.1007/s11356-019-06550-8 . hal-03089854

\section{HAL Id: hal-03089854 https://hal.science/hal-03089854}

Submitted on 28 Dec 2020

HAL is a multi-disciplinary open access archive for the deposit and dissemination of scientific research documents, whether they are published or not. The documents may come from teaching and research institutions in France or abroad, or from public or private research centers.
L'archive ouverte pluridisciplinaire HAL, est destinée au dépôt et à la diffusion de documents scientifiques de niveau recherche, publiés ou non, émanant des établissements d'enseignement et de recherche français ou étrangers, des laboratoires publics ou privés. 


\title{
Environmental Science and Pollution Research \\ "Modern agriculture" transfers many pesticidest towatercourses: acasestudy of a representative rural catchment of southern Brazil
}

José Augusto Monteiro de Castro Lima ${ }^{\mathrm{a}}$, Jérôme Labanowski ${ }^{\mathrm{b}}$, Marília Camotti Bastos ${ }^{\mathrm{c}}$, Renato Zanella ${ }^{\mathrm{c}}$, Osmar Damian Prestes ${ }^{\mathrm{c}}$, Jocelina Paranhos Rosa de Vargas ${ }^{\mathrm{c}}$, Leslie Mondamert $^{\mathrm{b}}$, Eugenie Granado ${ }^{\mathrm{b}}$, Tales Tiecher ${ }^{\mathrm{d}, *}$, Mohsin Zafar ${ }^{\mathrm{e}}$, Alexandre Troian ${ }^{\mathrm{c}}$, Thibaut Le Guet ${ }^{\mathrm{b}}$, Danilo Rheinheimer dos Santos ${ }^{\mathrm{c}}$

${ }^{a}$ Instituto Federal de Alagoas, Rua Odilon Vasconcelos, 103, Maceió, AL, Brazil. CEP 57035-350

${ }^{b}$ Université de Poitiers, IC2MP, UMR CNRS 7285, 7 rue Marcel Dore, B16, 860073 cedex 9, Poitiers, France.

${ }^{c}$ Universidade Federal de Santa Maria, Avenida Roraima, 1000, Santa Maria, RS, Brazil, CEP 97105-900.

${ }^{d}$ Universidade Federal do Rio Grande do Sul, Bento Gonçalves, 7712, 91540-000, Porto Alegre, RS, Brazil

${ }^{e}$ University of Poonch Rawalakot, Azad Jammu and Kashmir, Pakistan, Zipcode 12350.

* Corresponding author: T. Tiecher. Email: tales.tiecher@ufgrs.br

\begin{abstract}
The total cultivated area in Brazil reached to 62 million ha in 2018, with the predominance of genetically modified soybean and corn (36 and 17 million ha, respectively) in no-tillage systems. In $2018,5.3 \times 10^{5} \mathrm{Mg}$ of active ingredient of pesticides was applied in cropfields, representing about 7.3 liters of commercial product by habitant. However, the monitoring of water courses contamination by pesticides remains scarce and are based on traditional grab sampling systems. In this study, we used the grab (water) and passive sampling (Polar Organic Chemical Integrative Sampler - POCIS) to monitor pesticides contamination in the river network of a representative agricultural catchment of southern Brazil. We selected 18 sampling sites located in tributaries and in the main course of the Guaporé River, in Rio Grande do Sul State, with different land use predominance including forest, urban and agricultural areas. Altogether, 79 and 23 pesticides were, respectively, analyzed in water and POCIS samples. The water of Guaporé River and its tributaries were highly contaminated by many pesticides, especially by four herbicides (2.4-D, atrazine, deethyl- atrazine and simazine), three fungicides (carbendazim, tebuconazole and epoxiconazole) and one insecticide (imidacloprid). The amount, type and concentration of pesticides detected were completely different depending on the sampling technic used. POCIS were effective to discriminate the contamination according to the main land use of each sampling site. The monitored areas with the predominance of soybean cultivation under no-tillage tended to have higher concentrations of fungicide, while in the more diversified region the herbicides showed higher values. The presence of five herbicides used in corn and grasslands forage production was correlated with areas of integrated crop-livestock systems; in contrast to higher contamination by $2,4-\mathrm{D}$ in areas of intensive production of soybean and winter cereals.
\end{abstract}

Keywords: Environmental monitoring, Polar Organic Chemical Integrative Sampler, Water Contamination

\section{Introduction}

In southern Brazil there are more than 850 thousand family farms. In this region, 20 million hectares are occupied by more than 2.3 million people working exclusively in rural activities in and producing about $80 \times 106 \mathrm{Mg}$ of soybean, corn, rice and wheat in 2017, representing 36\% of Brazilian national production (IBGE, 2019). Even if soybeans as the main crop, there is a great diversity of production, including fruits and vegetables. Indeed, more than $90 \%$ of swine and poultry meat, approximately $50 \%$ of milk and almost $100 \%$ of tobacco are produced in this macro-region. 
Approximately $143 \mathrm{Mg}$ of active ingredients of pesticides are dispersed in a rural environment densely populated, even small towns which surrounded by crops. This macro-region has one of the most important surface water reserves of South America, except to Amazon catchment. Furthermore, it has one of the largest aquifers in the world, Guarani Aquifer, which also involves part of Paraguay, Argentina and Uruguay.

The transformation of natural biomes such as Pampa and Atlantic Forest in southern Brazil into cropfields tremendously decreases the infiltration of rainwater which results in increasing runoff and soil losses. The intensive land use combined with high intensity rainstorms make this region one of the global erosion hotspots (Borrelli et al., 2017). Results obtained by using the fingerprinting approach to investigate sediment origin in south Brazil revealed that about $90 \%$ of sediments present in Guaporé River (state of Rio Grande do Sul) come from cropfields, and the remaining from stream channels and unpaved roads (Tiecher et al., 2017). Accordingly, to these authors, this occurs because of the high connectivity of erosive processes from hillslopes to the stream network in Guapore River catchment, were there is a lack of mechanical runoff control strategies and absence of crop rotation. The main agricultural use is based in mono-cropping system of soybean in upper part and tobacco in middle/lower part of this catchment. There is also intensive integrated crop- livestock systems for milk production that results in lower soil cover by plant residues. Moreover, this region presents a rapid displacing of soil water by new rainfall events (Robinet et al., 2018). Accordingly, this scenario may result in high transfer the soluble and colloidal pesticides to the watercourses. In southern Brazil, there is a great diversity of soil type and agricultural production systems. There are reports in the literature of studies that have focused on specific molecules in irrigated rice cultivation areas and the effect of pesticides used in rice fields on the oxidative stress of fish in a rice-fish system (Clasen et al., 2012; 2018). Water and fish contamination in catchments with a predominance of tobacco cultivation (Bortoluzzi et al., 2006; Becker et al., 2009), as well as glyphosate contamination in areas with predominance of soy/corn/wheat cultivation under no-tillage has also been studied (Fernandes et al., 2019). However, the impact of pesticide contamination on more complex catchments with contrasting cultivation systems, such as the Guaporé River catchment, needs to be better understood in order to more holistically assess the effect of contamination generated by agricultural activities on aquatic systems. It is also important to evaluate a more diverse number of molecules and sampling strategies to generate information that can be used for river basin monitoring programs.

In 2018, 5.3 x $105 \mathrm{Mg}$ of active ingredients of pesticides were applied in Brazil (IBAMA, 2019). However, global estimates indicate that only $1 \%$ of applied amount reaches the target organisms. The remaining $99 \%$ of pesticides remains in the soil, water, and atmosphere, being eventually absorbed by non-target organisms (Zhang et al., 2011). The transport of pesticides from crops to other environmental compartments is mostly done by water through preferential flow and/or surface runoff. As a result, pesticides, especially polar and highly soluble ones, are found in surface and ground waters (Masiá et al., 2013).

The occurrence of pesticides in the aquatic environment has been reported worldwide (Fernandes et al., 2019; Schreiner et al., 2016; Michel et al., 2016; Masiá et al., 2013; Rabietet al., 2010; Bortoluzzi et al., 2006 and 2007). However, they are often found at concentrations below $1 \mu \mathrm{g}$ $\mathrm{L}-1$, requiring the use of sensitive methods and equipment that achieve low detection limits (Terzopoulou \& Voutsa, 2016). Most analytical methods and grab water sampling techniques have limited ability to provide holistic assessment of exposure to pesticides (Petty et al., 2004). The monitoring of the Morcille stream (France) over a year, confirmed that discrete sampling was not suitable for the accurate measurement of the level of exposure to pesticides in surface waters, stating that grab sampling largely underestimated pesticide concentrations and fluxes transiting through the stream (Rabiet et al., 2010).

An alternative is to employ passive sampling devices like the Polar Organic Chemical Integrative Sampler (POCIS). Theory and modelling about passive samplers have been largely described elsewhere (Alvarez et al., 2005; Huckins et al., 1993; Stuer-Lauridsen, 2005; Vrana et al., 2005; Morin et al., 2012; Ibrahim et al., 2013; Bayen et al., 2014). There is evidence that the accumulation of target compounds by POCIS is a dynamic process, with adsorption and desorption on the sorbent occurring in response to ambient levels of the target compounds in water (Metcalfe et al., 2014). Hence, the POCIS is a passive sampling technology that has been developed to accumulate trace levels of pesticides to provide time-integrated average concentrations for individual compounds 
in water.

Metcalfe et al. (2019), using POCIS for monitoring the pesticides in several catchments in the Great Lakes in Ontario, make evident the relationship between frequency and concentration of many pesticides (2,4-D, atrazine, carbendazim, tebuconazole and imidacloprid, especially) in watercourses and proportion of cropfields (soybean, corn and wheat). The POCIS was more adequate than active sampling for pesticides present in very low concentration. Challis et al. (2018), also in Canada (Red River - Lake Winnipeg), showed that using POCIS was possible to estimate the main sources of pesticides (i.e., atrazine from the United States and neonicotinoid both from Canadian and the United States agriculture fields) and signaled the time-scale concerning application and detection in surface water. Guibal et al. (2017), working in headwaters in two small catchments in France, aware to difficulty for monitoring the pesticides frequency and concentration fluctuation using active or passive sampling. They identified the three possible types of behavior (active $>,=$ and $<$ POCIS) when compared grab and passive sampling in relation to pesticides concentration. We know that the time of concentration of agriculture hillslope catchment is very fast (fromminutes to some hours) and the peaks of pesticides concentration occurs only after a few days of the application time in the cropfields (Liess et al., 1999) and after, the pesticides concentration may be not detected in the water column. However, the use of POCIS allows the accumulation of compounds that persist at low concentrations in surface waters (Terzopoulou and Voutsa, 2016; Metre et al., 2016). Moreover, it enables to decrease the high variability remaining when using grab sampling.

In this study, we compared the active and passive water sampling to evaluate the pesticides concentration in Guaporé River (Rio Grande do Sul State, Brazil) and its tributaries in order to understand the role of soil use and management on degree of contamination of surface water in the region

\section{Materials and Methods}

\subsection{Catchment Description}

The Guaporé River catchment is located in the south of Brazil, Rio Grande do Sul State between plane coordinates 420.900 - $366.400 \mathrm{mE}$ and 6.874.286 - 6.772.536 mS, zone 22S. The Guaporé River, which is the main watercourse, is $153 \mathrm{~km}$ long and drains an area of 2,490 $\mathrm{km}^{2}$. The average monthly flow rate was $31.3 \mathrm{~m}^{3} \mathrm{~s}^{-1}$ in 2012 and 2013 (Scotto, 2014). Sediment production in 2012 amounted to $390.2 \mathrm{Mg} \mathrm{km}^{-2}$ year $^{-1}$, and the average from 2000 to 2010 was estimated at $140 \mathrm{Mg}$ $\mathrm{km}^{-2}$ year $^{-1}$, with runoff coefficient of up to $31 \%$ (Didoné et al., 2014).

The average annual temperature is $17.9{ }^{\circ} \mathrm{C}$ and average annual minimum and maximum temperatures are 12.6 and $24.7^{\circ} \mathrm{C}$, respectively (Cfa Köppen system). Average annual rainfall varies between 1,550 and $1,700 \mathrm{~mm}$, but the annual minimum and maximum rainfall is 950 to $2,500 \mathrm{~mm}$, respectively (BRASIL, 1986). In this catchment, in previous studies conducted revealed that the rain events have high erosion potential (8,800 MJ mm ha-1 h-1 yr-1) (Didoné et al., 2014) with greater occurrence from July to November (INMET, 2019). The main soil classes, in the FAO Classification, are Acrisols (14.8\%), Ferralsols (33.8\%), Luvisols (24.9\%), Regosols (3.1\%) and Nitosols (23.3\%).

In the upper third of the catchment, where the relief is nearly level to gently sloping and predominated by Ferralsols, the farmers are practicing the no-tillage system from past two decades. There is a very direct relationship between soybean (Glycine max L. Merr.)_ultivation, livestock/swine, and poultry production in the catchment in spring/summer. The animals reside in marginal noncultivated areas, generally and along the watercourse. The farmers use high doses of herbicides and fungicides to soybean production, including the 2,4-D for resistant plant to glyphosate. The Nitosols covers almost $100 \%$ of the surface of Marau River tributary sub-catchment. In this area family agriculture integrated to livestock, especially, production of corn silage in spring and summer and winter grasslands forage to milk production. In addition, almost all farmers have also swine and poultry production activities. In the Marau River tributary there are 2.9 and 9.7 times corn and corn silage and -1.3 times soybean density production $\left(\mathrm{Mg} \mathrm{km}^{-2}\right)$ than in the source of Guaporé River.

In the other two-thirds (middle and lower) of the catchment, land use is more diverse and conventional soil management predominates in shallow soils with rocky surface (Luvisols, Acrisols and Regosols). The cultivated surface is imbricated in landscape and the family farmers have less than 10 hectares. In this region there are 1.3 and 1.6 times corn and corn silage and -4.2 times soybean density production than in the upper third of the catchment. This region has the biggest density of 
tobacco (Nicotiana tabacum L.) and erva- mate (Ilex paraguariensis St. Hill) production of Brazil. There is also integrated poultry and pig farming systems as well as dairy farming. The main land use in this area is cropland (60.0\%), natural forest (30.1\%), pastureland (5.6\%), forestry $(3.1 \%)$, urban areas $(0.6 \%)$ and water bodies $(0.4 \%)$ (Figure 1$)$

\subsection{Sampling Sites}

Were selected 18 sampling sites, located in the Guaporé River (G1, G2, G3, G4, G5, G6, G7, G8, G9 and G10), Marau Stream Tributary (M1, M2, M3 and M4), Lajeado Carazinho Stream Tributary (LC1, LC2 and LC3) and Carazinho Sream Tributary (C1). Descriptions of each site and locations are shown in Table 1 and Figure 1, respectively.

\subsection{Active Water Sampling}

The water sampling was performed between 11 and 13 December 2014, after a high precipitation event (89 mm - INMET, 2019). The soybean was in the V3 stage, the corn was in R1 stage and the first leaf of flue cured tobacco was harvest. The bottles were cleaned with neutral detergent and $\mathrm{HNO} 310 \%$ for $12 \mathrm{~h}$ and after with osmotic water and methanol. One liter of water was stored in an amber bottle, maintained at $4{ }^{\circ} \mathrm{C}$ in thermic boxes, and transported to Pesticides Residues Analysis Laboratory of Federal University of the Santa Maria, in Brazil.

\subsection{Passive Sampling - Polar Organic Chemical Integrative Sampler}

The samplers were made of 316 stainless steel with the following dimensions: $102 \times 54 \times 3$ $\mathrm{mm}$ (outside diameter, inside diameter and thickness); containing five $7 \mathrm{~mm}$ holes, two on the central axis, $6 \mathrm{~mm}$ from the inner edge and three in the shape of an equilateral triangle with $67.5 \mathrm{~mm}$ sides. SUPOR ${ }^{\circledR}$ Polyethersulfone filtering membrane with $0.1 \mu \mathrm{m}$ pores and $90 \mathrm{~mm}$ diameter (Petty et al., 2002) was used. The sorbent consisted of $200 \mathrm{mg}$ of OASIS ${ }^{\circledR}$ HLB resin $(30 \mu \mathrm{m}$ particle diameter $)$ with hydrophilic and lipophilic balance.205 Such devices were installed at the sampling sites in June 2015, fixed to be submerged during 15 days and protected by an iron box with an aluminum screen to allow water flow and act as a physical barrier against branches and stones. After fourteen days of exposure, the POCIS were collected, cleaned, packaged wrapped with aluminum foil, arranged in plastic bags in a cooler with ice and transported to the laboratory. In this period less than $1 / 5$ of the total agricultural surface is cultivated with wheat, barley and winter grasslands forage. There is a very low rate of pesticide application, comparatively to spring/summer season.

\subsection{Analytical Procedure}

In the laboratory, the pesticides present in water samples were extracted on Solid Phase Extraction using $200 \mathrm{mg}$ of adsorbing Strata X cartridge. The pesticides determination was performed in an Ultra High-Performance Liquid Chromatography, tandem mass spectrometry Acquity UPLC® pump with the triple quadruple Xevo TQ ${ }^{\circledR}$ (Waters). The mass spectrometer was operating in Selected Reaction Monitoring using an electrospray source positive ionization. 79 pesticides were monitored: 2,4-D, atrazine, azinphos-ethyl, azinphos- methyl, azoxystrobin, bentazone, bispyribac sodium, bitertanol, boscalid, bromoconazole, buprofezin, carbaryl, carbendazim, carbofuran, carborfuran-3-OH, carboxin, cianazin, chlorimuron, chlorpyriphos-éthyl, chlorpropham, diazinon, dichlofluanid, difenoconazole, dimethoate, epoxiconazole, fenpropathrin, fenpropimorph, fenarimol, fenthion, fipronil, fluquiconazol, fluroxypyr, flutolanil, imazalil, imidacloprid, iprovalicarb, linuron, malathion, mecarbam, mepronil, metalaxyl, metconazole, methiocarb sulfone, methiocarb sulfoxide, metsulfuron-methyl, mevinphos, myclobutanil, monocrotophos, monolinuron, oxamyl, paraoxonethyl, pendimethalin, pyraclostrobin, pyrazophos, pyrridiphention, pyrimethanil, pyrimicarbe, pirimiphos-methyl, profenofos, propiconazole, propyzamide, propoxur, quinclorac, quinoxyfen, simazine, tebuconazole, terbufos, tetraconazole, thiacloprid, thiamethoxam, thiodicarbe, tolclofosmethyl, triadimefon, triadimenol, triazofos, trichlorfon, trifloxystrobin, triflumizole, and vamidothion. The POCIS adsorbent material was transferred to cartridges with the aid of ultrapure water, then dried first under vacuum in a SPE manifold with N2 flow. Elution of the cartridges was done on a Thermo Scientific ${ }^{\mathrm{TM}}$ Dionex $^{\mathrm{TM}}$ AutoTrace ${ }^{\mathrm{TM}} 150$ Solid-Phase Extraction system with methanol. The extracts were evaporated under $\mathrm{N} 2$ flow and then reconstituted in $500 \mu \mathrm{L}$ of a methanol: water $(10: 90, \mathrm{v} / \mathrm{v})$ mixture. This method has been successfully used for elution of POCIS in a previous study. For 
quantification purposes, the standard curve method was used with all the pesticides under examination at concentrations of $0,5,10,15$ The analysis was carried out on an ultrahighperformance liquid chromatography (UHPLC) system (Thermo) with an electrospray source coupled to a quadrupole-time-of- flight mass spectrometer (Q-TOF) (Brucker). Three injections of $20 \mu \mathrm{L}$ in positive and negative mode for each extract were done. Data processing and treatment were done using Compass Data Analysis 4.2 and Target Analysis software. The presence of each compound was confirmed according to three criteria: the exact mass and the mass spectrum of the compound compared with the exact mass and the mass spectrum of a certified standard solution of this compound, and the retention time determined in the analytical conditions The concentration of pesticides adsorbed in POCIS resin was carried out by adjusting the linear model used between the concentration of the standards and the peak area of each injection for each compound detected. Detection limits were calculated from the standard derivation of calibration curves. Due to variability for each compound, an over evaluated value of $1 \mu \mathrm{g} \mathrm{L}-1$ was considered. A total of 23 compounds were analyzed, namely: 2,4-D, atrazine, boscalid, carbendazim, chlorotoluron, chlorpyriphos-éthyl, deethyl- atrazine, dicamba, epoxiconazole, imidacloprid, iodosulfuron-methyl-sodium, isoproturon, MCPA, mesotrione, mesosulfuron-methyl, metconazole, nicosulfuron, prochloraz, prosulfuron, prothioconazole, simazine, tebuconazole, thifensulfuron-methyl. To evaluate the time average concentration of waters, Rs value from literature were use [ Fauvelle et al. $2104(2,4-\mathrm{D}=0.08)$, Mazella et al. 2010 (atrazine $=0.24$; deethylatrazine $=0.17$; simazine $=0.21$ ), Ahrens et al. 2015 (carbendazim $=0.22 ;$ epoxiconazole $=0.17 ;$ imidacloprid $=0.18 ;$ thifensulfuron-methyl $=0.02$; mesosulfuron-methyl $=0.06$ ), Belles et al. 2013 (tebuconazole

$=0.19$; prosulfuron $=0.12$ ) and Mazella et al. 2007 (nicosulfuron $=0.04)$ ]. All data regarding to development of analytical methods are available in supporting material.

2.6 Potential Ecological Risk The predicted no effect concentration of each pesticide was calculated by dividing the concentration obtained in the literature responsible for causing some physiological damage or death of the standard species by an evaluation factor (EMEA, 2006). In this study, we assess the potential ecological risk for two species: (i) Daphinia magna, which is a crustacean used worldwide in ecotoxicological tests because of its sensitivity to environmental changes, and (ii) silver catfish (Rhamdia quelen), a fish commonly found in rivers in the southern region of Brazil. For Daphnia magna $M$. the critical concentrations found in the literature were: $2,4-\mathrm{D}=25.0 \mathrm{mg} \mathrm{L}^{-1}$ (Toussaint et al., 1995); atrazine and deethyl-atrazine $=50.4 \mathrm{mg} \mathrm{L}^{-1}$ (Moreira et al., 2014); simazine = $4.2 \mathrm{mg} \mathrm{L}^{-1}$ (Arufe et al., 2004); carbendazim $=0.005 \mathrm{mg} \mathrm{L}-1$ (Silva et al., 2015); tebuconazole $=40.1$ mg L-1 (Sancho et al., 2008); and imidacloprid $=96.0 \mathrm{mg} \mathrm{L}-1$ (Loureiro et al., 2010). For silver catfish the critical concentrations found in the literature were: 2,4-D $=0.20 \mathrm{mg} \mathrm{L}^{-1}$ (Glusczak et al., 2007); atrazine and deethyl-atrazine $=10.2 \mathrm{mg} \mathrm{L}-1$; simazine $=8.9 \mathrm{mg} \mathrm{L}-1$; tebuconazole $=4.8 \mathrm{mg} \mathrm{L}$ ${ }^{1}$ (Kreutz et al., 2008); carbendazim $=1.5 \mathrm{mg} \mathrm{L}-1$ (Sridhar \& Joice, 2012); imidacloprid $=78.0 \mathrm{mg} \mathrm{L}^{-1}$ (Tyor \& Harkrishan, 2016). The evaluation factor values were set at 1000, according to the suggestion of the European Commission Technical Guidance Document and Guidelines for the Implementation of REACH (2006). The potential ecological risk (RQi) for each pesticide studied and potential ecological risk mix (RQmix) was quantified using the ratio between the measured environmental concentration and the predicted no effect concentration (Stehle \& Schulz, 2015; Di Lorenzo et al., 2018; Kienzler et al., 2019Nie et al., 2015; Yao et al., 2017, Backhaus and Faust, 2012). The common risk ranking criteria are as follows: $0.01<\mathrm{RQ}<0.1$ is considered low risk, $0.1<\mathrm{RQ}<1$ is considered medium risk, and RQ> 1 is considered high risk (Hernando et al., 2006).

2.7 Statistical treatment The Kolmogorov-Smirnov and Lilliefors tests were used to assess whether the concentrations of pesticides exhibited a normal distribution. As the results did not show normal distribution, the median was used as a measure of position, and the upper and lower quartiles, interquartile range, and maximum and minimum values as dispersion measures. The hypothesis that the systems of land use and management practiced in the northern and southern regions of the catchment contribute differently to the contamination of aquatic ecosystems by pesticides was statistically evaluated by the Mann-Whitney $U$ nonparametric test. 3. Results and discussion

3.1 Grab Water Sampling None of the water samples collected from the National Forest contained pesticide residues. However, all others 17 water samples were contaminated with at least one pesticide. Of the 79 monitored pesticides, 11 were detected in the water samples (atrazine, simazine, propoxur, imidacloprid, carbendazim, azoxystrobin, thiamethoxam, fipronil, propiconazole, 
tebuconazole and carbofuran) (Figure 2). The two representative triazines pesticides (atrazine and simazine) were detected, respectively, in 94 and $89 \%$ of samples collected in Guaporé River and its tributaries (Table 2). It shows that this pesticides class (high log Kow 2.3-2.7 and low solubility 3.5$5.0 \mathrm{mg} \mathrm{L}-1$ - Lewis et al., 2016) are systematic transferred to the superficial watercourses in Brazilian agroecosystems (Armas et al., 2007; Azevedo et al., 2010; Moreira et al., 2012), and can be persist in the water and aquatic biota (Jablonowski et al., 2009; Bohn et al., 2011). These herbicides are, respectively, 3 and 6 most used in southern of Brazil (IBAMA, 2019). The 2,4- D was not detected despite its indiscriminate use (only surpassed by glyphosate) in Brazil and southern Brazil (57.4 and 14.8 Mg in 2017, respectively), due to its physicochemical properties (low Kow -0.82; high solubility $24.3 \mathrm{~g} \mathrm{~L}-1$ and low half life time 4.4 days - Lewis et al., 2016). The 2,4-D transfer in the fluvial network is conditioned to the time of application and intensity of rainfall, which change the speed and flow of rivers. The active sampling is more adequate to detect this type of pesticides (Silva et al., 2014). The water of Guapore River and its tributaries contain many insecticides (carbamates: propoxur and carbofuran; nicotinoids: imidacloprid and thiamethoxam; and pyrazole: fipronil). The neonicotinoids were detected in about $50 \%$ of water samples, and confirm previous data published with superficial water monitored near to the Guaporé catchment (Bortoluzzi et al., 2006 and 2007; Sequinatto et al., 2013). The neonicotinoids pesticides use increased in the last two decades in about 120 countries in order to replace the organophosphates and carbamates insecticides (Jeschke et al., 2011), in contrast of interdiction in European Union after 2018. The systemic pesticides replace the contact pesticides with very active periods within the plant and acts against sucking insects, but also against beneficial insects such as bees. In southern Brazil the imidacloprid consummation increased eight times between 2009 and 2017 (IBAMA, 2019), and it has a very high potential for increased consumption because organophosphate is still seven times more consumed than neonicotinoids. Indeed, in $78 \%$ of water samples we detected propoxur insecticide, which is recommended to use in animals' production. Moreover the Guaporé catchment represents the highest concentration of swine and poultry in Brazil (FEE, 2019). Its low capacity of adsorption to colloids (Koc $=30 \mathrm{~mL}$ g- 1 and $\log$ Kow $=0.14)$, high solubility $\left(1800 \mathrm{~g} \mathrm{~L}^{-1}\right)$, and high half life-time (180 days) make the propoxur very disperse in surface watercourse. The fungicides were detected in 11 monitored sites, especially those used in soybean production, such as the carbendazim (moderate Koc $=225 \mathrm{~L} \mathrm{~kg}-1$, low Kow $=$ 1.48 , and high half life time $=350$ days). While Singh et al. (2016) warned that this insecticide was banned in developed countries (Australia and most European countries), in Brazil its consumption is still extremely high (3.7 Mg in 2017 - IBAMA, 2019). The highest pesticides concentration and variability between monitored sites were observed for pesticides with the highest frequency of occurrence in Guaporé River and its tributaries (Figure 2). The medians concentration of atrazine and simazine were the highest among the pesticides monitored $(680$ and $190 \mathrm{ng} \mathrm{L}-1)$ and have also the highest spatial variability interquartile range (IQR of 1,000 and $150 \mathrm{ng} \mathrm{L}^{-1}$ ), and with $75 \%$ of concentration higher than 380 and $90 \mathrm{ng} \mathrm{L}^{-1}$, respectively. For carbendazim, propoxur, imidacloprid and thiamethoxam analyses showed that $75 \%$ of the concentration was lower than $80,60,50$ and 15 ng $\mathrm{L}^{-1}$ for, respectively. According to Brazilian legislation (BRASIL, 2005) the water from all monitored sites in Guaporé River catchment have been classified as "Special Class" and can be consumed by humans after a disinfection treatment. This classification allows the presence of glyphosate $\left(65 \mu \mathrm{g} \mathrm{L}^{-1}\right)$, alachlor $\left(20 \mu \mathrm{g} \mathrm{L}^{-1}\right)$, metolachlor $\left(10 \mu \mathrm{g} \mathrm{L}^{-1}\right), 2,4-\mathrm{D}\left(4 \mu \mathrm{g} \mathrm{L}^{-1}\right)$, atrazine $(2 \mu \mathrm{g}$ $\left.\mathrm{L}^{-1}\right)$ and simazine $\left(2 \mu \mathrm{g} \mathrm{L}{ }^{-1}\right)$. Comparing pesticides concentrations obtained by grab sampling with the values allowed by the Brazilian legislation all sites could be used as a source of water for a drinking water treatment station. However, this_egislation is very permissive when compared with other countries, for example France law. In France the quality limits for raw water of any origin used for the production of water, intended for human consumption, are limited to $2 \mu \mathrm{g} \mathrm{L}^{-1}$ for individual concentrations and $5 \mu \mathrm{g} \mathrm{L}^{-1}$ for the sum of pesticides. Based on this, if these values were compared with the France legislation, the grab samples satisfied these criteria. Nevertheless, POCIS sampling exhibited that pesticides concentrations values are largely above restrictive limits of French law.

3.2. Passive Sampling - Polar Organic Chemical Integrative Sampler The use of POCIS enabled the detection of 2,4-D, atrazine, deethyl-atrazine, simazine, carbendazim, tebuconazole, epoxiconazole, imidacloprid, mesotrione, nicosulfuron, thifensulfuron-methyl, mesosulfuron-methyl and prosulfuron in the waters of the Guapore River and its tributaries (Table 2 and Figure 3). All the sampling sites showed the presence of at least four of the 23 pesticides monitored, except in the National Forest site. 
The uses of POCIS indicate that the pesticides, even months after their use, were transferred and detected in river ecosystems, in periods with low concentration. Therefore, the use of POCIS could avoid the problem of false negatives common in times of low pesticide use in agricultural fields, periods of low rainfall intensity and/or high rate. The POCIS exposed for 14 days provided the accumulation of the pesticides present in the water of the Guapore River and its tributaries to such an extent that it enabled its quantification active sampling. These results have been evidenced in several studies evaluating the occurrence of organic contaminants such as pesticides, polychlorinated biphenyls, flame retardants and pharmaceuticals (Alvarez et al., 2005; Dalton et al., 2014; Schopfer et al., 2014; Martínez Bueno et al., 2016; Gonzalez-Rey et al., 2015). This displays the relevance of this tool for assessing the water quality compared to the traditional sampling system. The frequency of quantification of atrazine, deethyl-atrazine, azoxystrobin, epoxiconazole, imidacloprid, simazine and tebuconazole in the waters was systematically enhanced with the use of POCIS (Poulier et al., 2014). These results suggest that the contamination of Brazilian waters is being underestimated when using "active" grab water sampling. Among the herbicides, triazines (atrazine, deethyl-atrazine and simazine) and aryloxyalkanoic acid (2,4-D) chemical groups were detected in 94 to $100 \%$ of the sampled sites, respectively (Table 2). After glyphosate (IBAMA, 2019), the 2,4-D, atrazine and simazine are the most widely used pesticides in southern of Brazil and in the Guapore River catchment,. Fernandes et al. (2019) showed that epilithic biofilms occurring in Guaporé River catchment were impregnated by glyphosate (10 to $305 \mu \mathrm{g} \mathrm{kg}-1)$ and your metabolite AMPA (50 to $670 \mu \mathrm{g} \mathrm{kg}-1)$ and are strongly influenced by the amount of herbicide applications. In general, the use of these compounds begins in June with the preparation of areas for the sowing of wheat and extends through January with the end of the corn and soybean planting season. The highest application volume is concentrated between the months of October and January, including for the others spring/summer cultures like tobacco and bean (Phaseolos vulgaris L.). Between January and June, the use of insecticides and fungicides are higher than the herbicide periods of vegetative and reproductive development of soybean and corn. The POCIS captured mesotrione, nicosulfuron, thifensulfuronmethyl, mesosulfuron-methyl and prosulfuron only in the Marau tributary sites and upstream of the Lageado Carazinho tributary. These herbicides were recommended and used in corn and grasslands forage production. The POCIS was also effective in detecting some fungicides in the Guapore River network. Fungicides of the benzimidazole and triazole groups (in descendant order, carbendazim, tebuconazole and epoxiconazole) are those with the highest occurrence (Figure 3 and Table 2). However, anilide, imidazolecarboxamide and triazolinethione groups were not detected. Imidacloprid was detected in $75 \%$ of the sampling sites of the Guapore River and its tributaries (Table 2). Conversely, chlorpyrifos (organophosphate) was not detected in the water of any of the sampling sites. This most likely happened due to its high octanol-water partition coefficient $($ Kow $=4.7)$, which ensures higher retention of these compounds in nonpolar matrices, reducing its concentration in solution and consequently reducing its exposure to the POCIS and its detection in water samples. Therefore, chlorpyrifos was not sequestered in the POCIS because of the reduced exposure time of the POCIS in the field, since it is commonly used by farmers (IBAMA, 2019). The uptake of less polar compounds ( $\log$ Kow > 3.7) is strongly influenced by the exposure time of the POCIS (Silva et al., 2014). This characteristic, in addition to affecting the availability of the concentration in solution,_also affects the diffusion of these pesticides between the two phases: from membranes with $0.1 \mu \mathrm{m}$ porosity to the adsorbent. In the box-plots (Figure 4), the median location in the interquartile range of the pesticides confirms the results obtained by the Kolmogorov-Smirnov \& Lilliefors test, that the data is unlikely to present normal distribution. Therefore, they are presented with the median, quartiles, minimum and maximum values. The herbicide class showed a higher concentration in the Guaporé River waters. 2,4-D stands out for two reasons, such as: (i) exhibited greater spatial variability between monitored points denoted in the IQR of $41,786 \mathrm{ng} \mathrm{L}-1$; and (ii) the value of the first quartile was similar or higher than the values of the third quartile of other compounds analyzed in this study. Atrazine had a median of $1,905 \mathrm{ng} \mathrm{L}-1$, an IQR of $2,857 \mathrm{ng} \mathrm{L}-1$, and $75 \%$ of the observations were at concentrations below $655 \mathrm{ng} \mathrm{L-1}$, five times less than the values found for 2,4-D. The lowest values found were of simazine, which presented median, IQR and first quartile values approximately 3 times lower than those of atrazine. The metabolite deethyl- atrazine showed similar behavior to simazine, but with higher amount accumulated in the POCIS sorbent. Among the fungicides, the variability between compounds and between the sampling sites was lower compared to 
the herbicides (Figure 4). For the median, IQR and first quartile values, the highest concentrations of fungicide present in the waters of the Guapore River and its tributaries were (in downward order): carbendazim, tebuconazole and epoxiconazole. Contrary to the herbicides, $75 \%$ of the values for these three fungicides are below 994; 368; and $109 \mathrm{ng} \mathrm{L}-1$. The interquartile range of carbendazim was 792 ng L-1, approximately 2.5 and 9.4 times than those of tebuconazole and epoxiconazole, respectively. Imidacloprid, the only representative of the insecticide class concentrated by the POCIS, was present in $75 \%$ of the sampled sites with concentrations below $786 \mathrm{ng} \mathrm{L}-1$, whose median was $548 \mathrm{ng} \mathrm{L}-1$ and the maximum concentration was 1,429 ng L-1 in the Guaporé River catchment. Although the use of the POCIS shows promise in improving the contaminant detection system in river waters, there are gaps of knowledge that must be overcome in order to obtain more realistic values of the concentration in the water derived from the amount sequestered, as well as for comparative purposes in each study and between studies. One of the issues is the lack of a method to satisfactorily correct in situ exposure conditions (water flow rates, temperature, $\mathrm{pH}$, incrustation, etc.), which are known to affect the uptake rates of more polar compounds (Harman et al., 2011 and 2012). Another factor is related to the variability in the retention of pesticides in the membranes that protect the adsorbent. The study of Lissalde et al. (2014) showed that depending on the speed of water ( 3 to $13 \mathrm{~cm} \mathrm{~s}^{-1}$ ) between the sampled rivers and the tested compound, the accumulation in the membrane may vary from 3 to $60 \%$ of the total concentration sequestered by the membrane/adsorbent. For more nonpolar compounds ( $\log$ Kow $>3$ ), these limitations were overcome using performance reference compounds. This was possible due to its dissipation following first order kinetics to the uptake kinetics and could therefore be used to estimate the sampling rates of target compounds in situ (Harman et al., 2011 and 2012; Booij et al., 1998). For the more polar compounds such limitations persist, there is a relationship between the flow rate and the reference compounds desorption, especially for speeds higher than $4 \mathrm{~cm}$ s-1 (Lissalde et al., 2014). However, the concentrations of 2,4-D, atrazine, carbendazim, simazine, imidacloprid and tebuconazole were higher than the highest concentrations (Metre et al., 2016) reported in previous studies, except for deethyl-atrazine, which presented lower concentrations than those found by Lissalde et al. (2014). If the interfering factors presented by Harman et al. (2011) are minimized, the higher intensity in pesticide use in southern of Brazil, associated with reduced adsorption of soil and water conservation practices will be the main differing factors among the reviewed studies. This hypothesis is based on soil and climate characteristics (high levels of soil organic matter and 2:1 clay mineral; and temperate climate) of the studied regions. Thus, reduced rates of physicochemical degradation of pesticides in the soil were expected, resulting in a higher pesticide load on water resources. In regard of deethyl-atrazine, Lissalde et al. (2014) presented neither justification for the high values found in comparison to other compounds or other studies, nor did they present sufficiently relevant environmental conditions to justify such behavior*

3.3. Potential ecological risk The surface water, generally, most of the sampling sites displayed low to medium ecological risk potential for the crustaceans Daphinia magnum and silver catfish by individual pesticides (Table 3). The 2,4-D and carbendazim concentrations could_represented a huge risk of contamination than other pesticides, for silver catfish and crustaceans, respectively (RQ $>>1$ - Hernando et al., 2006; Zeng et al., 2018). The access of these two pesticides can induce DNA damage and immobility and death to crustacean, respectively. Indeed, the 2,4-D can increase hepatic glycogen and reduce muscle glycogen (Glusczak et al., 2007) and carbendazim can cause the death of silver catfish (Sridhar \& Joice, 2012). The cumulative potential risk (RQmix) for both species were null for watercourse in National Forest, and very low in the two tributaries monitored in middle/lower region ofthe catchment for crustaceans. In contrast, both Guaporé River and Marau tributary (upper region), the water represents a high ecological risk for the crustaceans and in all monitored site for silver catfish because of the high 2,4-D concentration. Becker et al. (2009), using juvenile silver catfish maintained in cage for 30 days in a high (high concentration in imidacloprid and clomazone) and low contaminated watercourse next to Guaporé catchment, showed that the plasma glucose and hepatic glycogen levels of fishes were lowered, but it increased the plasma $\mathrm{K}+$ levels, values of hepatic glycogen, muscle lactate and protein of the kidney when exposed to water at the high than at low anthropic activity. Generally speaking, sites with forests maintain a very low level of risk. For all other sites, the use of carbendazim exposes daphnia to a very high risk. For fish, the risk is associated with the presence of 2,4 D. However, as each species responds differently to a given molecule, it 
means that the ecosystem as a whole is threatened by the presence of pesticides in the water in Guaporé catchment due to the high anthropogenic pressure in the agricultural land.

3.4 Effect of agricultural use and management systems It is known that in upper region prevail the transgenic soybean production in contrast to more diversified plant production in the middle/lower region (corn, tobacco, bean, etc.). In consequence, the type, doses and period of pesticides application are different in these regions. However, no differences in the diversity and concentration of pesticides between the upper and middle/lower region of the Guapore River catchment using grab sampling (Table 4). Punctual pulses of pesticides application are indeed detectable only at short period soon after its application. Moreover, the presence of natural barriers in the landscape will also be responsible for a decrease of pesticide transfer to river, because it_reduces runoff connectivity to stream network. These combined phenomena may maintain the concentrations of pesticides in watercourses at levels that cannot be distinguished between the upper and the middle/lower region of the catchment. Figure 5 presents the results of POCIS comparative analysis between the upper and middle/lower regions of the catchment by Mann Whitney $U$ test for each contaminant. No differences at $\mathrm{p}<0.06$ were found between the regions for 2,4-D, atrazine, deethyl-atrazine, simazine, epoxiconazole and imidacloprid. However, we found that the distributions of the values of carbendazim, tebuconazole and epoxiconazole are statistically different between the regions. Nevertheless, the waters of the Guaporé River and its tributaries in the middle/lower region had the highest median concentrations for all herbicides (2,4-D, atrazine, deethyl- atrazine, and simazine) and lower concentrations for all fungicides (carbendazim, epoxiconazole and tebuconazole) (Figure 5). The variability of the median concentration between the two macro-regions was 30 to $120 \%$ for herbicides and 67 to $270 \%$ for fungicides. The highest values found of atrazine and simazine in the Guaporé River and its tributaries in the middle/lower region of the catchment are consistent with higher corn density (124 and $258 \%$ for grains and silage, respectively), compared to the upper region, where soybean predominates (300\% more density). In general, herbicides (2,4-D, atrazine, deethylatrazine and simazine) are more mobile in the environment (Lewis et al., 2016) and have higher concentrations in the waters of the river network compared to fungicides (carbendazim, epoxiconazole and tebuconazole). This is due to the lower capacity of these herbicides to be adsorbed by colloids (low Koc and low Kow values), and therefore remain soluble in water and are easily transported during the occurrence of rainfall events of low to high intensity. They may even percolate into the soil profile and contaminate subsurface waters. Robinet et al. (2018), in a small subcatchment in a Guaporé River catchment, showed that although the event rainfall is the main component for the surface runoff, and that the soil water is quickly displaced with new rainfall events in agriculture catchment, signifying a contribution of deep groundwater to the streamflow. Furthermore, the presence of five other herbicides (mesotrione, nicosulfuron, thifensulfuron-methyl, mesosulfuron-methyl and prosulfuron) detected in the catchment was coherent with corn density. For example, Marau tributary and source of Guaporé River regions are neighboring, have even soil type, even relief, even soil management system, but differ sensibly in the soybean/maize ratio (191 and $870 \%$ more grain and silage corn density in Marau tributary) (FEE, 2019). In the upper region, the highest values of fungicides in the Guaporé River and its tributaries can be explained by conditions of agricultural use and management of the land. Soybean is the main crop in the spring/summer period, which preceded monitoring. The absence of crop rotation and the use of transgenic plants in $100 \%$ of the farms significantly increased the incidence of fungal disease and, consequently, the quantity and frequency of fungicide applications. The discriminant function analysis was also used to verify which pesticides improve the discrimination of the established groups according to the predominant land use and soil management systems. The eigenvalues and standardized coefficients for canonical variables are shown in Table 5. The calculated variance on the first and second axis was $100 \%$, with eigenvalue of 7.7. Four variables were maintained in the model. However, only carbendazim (partial $\lambda=0.19, \mathrm{~F}$ $=42.2$ and $\mathrm{p}=0.0001$ ), imidacloprid (partial $\lambda=0.53, \mathrm{~F}=8.9$ and $\mathrm{p}=0.0138$ ) followed by deethylatrazine (partial $\lambda=0.68, F=4.5$ and $\mathrm{p}=0.0593$ ) showed significant contributions (Table 5), and therefore, they confirm that the concentrations of these pesticides in the two regions were different. The values of tolerance (R2) and 1-R2 represent the correlation of the given variable with all other variables included in the model (Hair et al., 2009). Thus, the most informative variable is carbendazim $(\mathrm{R} 2=0.14)$. Samples from the upper region were well separated from middle/lower region samples along axis 1 , the average probability of uncertainty in the classification of the points 
was $0.31 \%$ and $0.00 \%$ in the upper and middle/lower regions, respectively. These results also indicate that the molecules that most contributed to differentiate the regions were carbendazim, deethylatrazine, imidacloprid and 2,4-D and, therefore, future studies on the impact of agricultural activities on pesticide contamination in southern Brazil should focus on these molecules. In the upper region, $100 \%$ of the crops are conducted under no-tillage. However, these cropfields present conservationist efficacy compromised by the removal of physical barriers to surface water runoff, low addition of plant biomass, and insufficient soil cover. In this context there is an increase in the susceptibility of contaminant transfer from terrestrial ecosystems to the aquatic ecosystem. Even if no-tillage reduces soil losses by more than $70 \%$, water losses are practically similar to other soil cultivation systems (Londero et al., 2018). In this sense, several authors have emphasized the importance of resuming the adoption of terraces and increasing the density of soil cover for environmental conservation purposes (Cogo et al., 2003; Didoné et al., 2017; Merten et al., 2015). The distance between the crops and the river is very narrow (width riparian forest lower than $15 \mathrm{~m}$ ). There is a high connectivity of erosive processes and the limited deposition of sediment in floodplains (Rheinheimer et al., 2017). The least polar and highly persistent and reactive pesticides in the soil, such as tebuconazole and epoxiconazole, present in practically all monitored sites tend to be occasionally transported to water during rainfall events of high or low intensity. Longer distance and lower connectivity of crops with the river network are necessary conditions to maintain the quality of surface water, reducing the deposition of sediments and the water flow that drive the pesticides transport, both adsorbed and in solution, respectively. Catchment-scale connectivity is still a complex process of understanding and difficult to measure (Michaelides \& Chappell, 2009; Fryirs, 2013; Koiter et al., 2013). However, it is known that in the middle/lower Guaporé catchment before reaching the water sources, the eroded sediments pass through successive processes of deposition and remobilization over time (Minella et al., 2014). Moreover, the small cultivated surface was imbricated in the landscape, and the watercourses were bordered by a great width riparian forest $(60$ to $>100 \mathrm{~m})$, resulting an efficient barrier to sediment (Tiecher et al., 2017) and pesticides transfer to the surface water (Bortoluzzi et al., 2007), even of more accidently relief and conventional soil management.

4. Conclusions Agriculture is a major sector of the Brazilian economy. One the main priority of the Brazilian agricultural policy is to create conditions to increase production and improve the productivity of family farming. Consequently, the use of pesticides is widely favored to allow "modern intensive agriculture" also in rural areas. The results obtained in this study demonstrate that there is a high ecological risk of contamination with pesticides, indicating that the current agricultural production systems are contaminating the waters of the Guapore River water and its tributaries, and highlighting that the current soil conservation practices are insufficient, even in the regions of the catchment where the use of no-till system predominates. The present work shows that the use of pesticides in rural catchments leads to the contamination of surrounding water resources. Thus, a very large variety of compounds was found in Guaporé River and its tributaries by grab or passive (POCIS) sampling, including 2,4-D, atrazine, simazine, deethyl-atrazine, carbendazim, epoxiconazole, tebuconazole and imidacloprid. Furthermore, the sampling by POCIS highlighted that a discriminant role of land use (type of culture, slope of soils) on the pesticide contamination. Thus, flat areas grown with high soybean density in a no-till system had higher levels of fungicide. However, streams near fields with various agricultural plantations had a higher concentration of herbicides. The presence of five herbicides used in maize, grassland and fodder production was linked to areas of integrated crop and livestock systems. In addition, the highest 2,4-D contamination was found in areas of intensive soybean and winter grain production. Facing the economic, social, sanitary and environmental issues, reconciling growth and sustainability in Brazil's agricultural development model is more than ever needed to maintain agriculture and to preserve water resources.

\section{Acknowledgments}

Coordination for the Improvement of Higher Education Personnel (CAPES). Brazilian National Council for Scientific and Technological Development (CNPq). Project "Mais Água" of FINEP/FEPAGRO/SEAPA-RS.

\section{References}


Ahrens, L., Daneshvar, A., Lau, A.E., Kreuger, J., 2015. Characterization of five passive sampling devices for monitoring of pesticides in water. Journal of Chromatography A 1405, 1-11.

Alvarez, D.A., Stackelberg, P.E., Petty, J.D., Huckins, J.N., Furlong, E.T., Zaugg, S.D., Meyer, M.T., 2005. Comparison of a novel passive sampler to standard water-column sampling for organic contaminants associated with wastewater effluents entering a New Jersey stream. Chemosphere 61, $610-622$.

Armas, E.D., Monteiro, R.T.R., Antunes, P.M., Santos, M.A.P.F., Abakerli, R.B., 2007. Diagnóstico espaço-temporal da ocorrência de herbicidas nas águas superficiais e sedimentos do rio Corumbataí e principais afluentes. Química Nova 30(5), 1119-1127_Arufe, M.I.,

Arellano, J., Moreno, M.J., Sarasquete, C., 2004. Comparative toxic effects of formulated simazine on Vibrio fischeri and gilthead seabream (Sparus aurata L.) larvae. Chemosphere 57(11), 1725-1732.

Azevedo, D.A., Silva, T.R., Knoppersb, B.A., Schulz-Bullc, D., 2010. Triazines in the Tropical Lagoon System of Mundaú-Manguaba, NE-Brazil. Journal of the Brazilian Chemical Society 21(6), 1096-1105.

Bayen, S., Segovia, E., Loh, L.L.L.L., Burger, D.F.D.F., Eikaas, H.S.H.S., Kelly, B.C.B.C., 2014. Application of Polar Organic Chemical Integrative Sampler (POCIS) to monitor emerging contaminants in tropical waters. Science of the Total Environment 482, 15-22.

Becker, A.G., Moraes, B.S., Menezes, C.C., Loro, V.L., Rheinheimer, D.S., Reichert, J.M., Baldisserotto, B., 2009. Pesticide contamination of water alters the metabolism of juvenile silver catfish, Rhamdia quelen. Ecotoxicology and Environmental Safety 72, 1734-1739.

Belles, A., Pardon, P., Budzinski, H., 2013. Development of an adapted version of polar organic chemical integrative samplers (POCIS-Nylon). Analytical and Bioanalytical Chemistry 406(4), 1099 1110 .

Bohn, T., Cocco, E., Gourdol, L., Guignard, C., Hoffmann, L., 2011. Determination of atrazine and degradation products in Luxembourgish drinking water: origin and fate of potential endocrinedisrupting pesticides. Food additives \& contaminants 28(8), 1041-54.

Booij, K., Sleiderink, H.M., Smedes, F., 1998. Calibrating the uptake kinetics of semipermeable membrane devices using exosure standars. Environmental Toxicology and Chemistry 17, 1236-1245.

Borrelli, P., Robinson, D.A., Fleischer, L.R., Lugato, E., Ballabio, C., Alewell, C., Meusburger, K., Modugno, S., Schutt, B., Ferro, V., Bagarello, V., Van Oost, K., Montanarella,L., Panagos, P., 2017. An assessment of the global impact of 21st century land use change on soil erosion. Nature Communications 8(1), 1-13.

Bortoluzzi, E.C., Rheinheimer, D.S., Gonçalves, C.S., Pellegrini, J.B.R., Zanella, R., Copetti, A.C.C., 2006. Contaminação de águas superficiais por agrotóxicos em função do uso do_solo numa microbacia hidrográfica de Agudo, RS. Revista Brasileira de Engenharia Agrícola e Ambiental 10(4), 881-887.

Bortoluzzi, E.C., Rheinheimer, D.S., Gonçalves, C.S., Pellegrini, J.B.R., Maroneze, A.M., Kurz, M.H.S., Bacar, N.M., Zanella, R., 2007. Investigation of the occurrence of pesticide residues in rural wells and surface. Química Nova 30, 1872-1876.

BRASIL. 1986. Projeto RADAMBRASIL, Folha SH. 22 Porto Alegre e parte das folhas SH. 21 Uruguaiana e SI. 22 Lagoa Mirim: geologia, geomorfologia, pedologia, vegetação, uso potencial da terra/ Fundação Instituto Brasileiro de Geografia e Estatística. Rio de Janeiro: IBGE, 796p. 
BRASIL. 2005. Resolução do CONAMA n 357, de 18 de março de 2005. Brasília, DF: Congresso Nacional.

BRASIL. 2011. Portaria no 2914, de 12 de dezembro de 2011. Ministério da Saúde. Diário Oficial da União. Poder executivo, Brasília, DF.

Challis, J.K., Cuscito, L.D., Joudan, S., Luong, K.H., Knapp, C.W., Hanson, M.L., Wong, C.S., 2018. Inputs, source apportionment, and transboundary transport of pesticides and other polar organic contaminants along the lower Red River, Manitoba, Canada. Science of the Total Environment 635, 803-816.

Clasen, B.E., Loro, V.L., Cattaneo, R., Moraes, B., Lópes, T., Avila, A.A., Zanella, R., Reimche, G.B., Baldissertotto, B. Effects of the commercial formulation containing fipronil on the non-target organism Cyprinus carpio: Implications for rice-fish cultivation. Ecotoxicology and Environmental Safety $77,45-51$

Clasen, B.E., Loro, V.L., Murussi, C.R., Tiecher, T.L., Moraes, B., Zanella, R., 2018. Bioaccumulation and oxidative stress caused by pesticides in Cyprinus carpio reared in a rice-fish system. Science of the Total Environment 626, 737-743.

Cogo, N.P., Levien, R., Schwarz, R.A., 2003. Perdas de solo e água por erosão hídrica influenciadas por métodos de preparo, classes de declive e níveis de fertilidade do solo. Revista Brasileira de Ciência do Solo 27, 743-753.

Dalton, R.L., Pick, F.R., Boutin, C., Saleem, A., 2014. Atrazine contamination at the watershed scale and environmental factors affecting sampling rates of the polar organic chemical integrative sampler (POCIS). Environmental Pollution 189, 134-142. solo numa microbacia hidrográfica de Agudo, RS. Revista Brasileira de Engenharia

Di Lorenzo, T., Cifoni, M., Fiasca, B., Di Cioccio, A., Galassi, D.M.P., 2018. Ecological risk assessment of pesticide mixtures in the alluvial aquifers of central Italy: Toward more realistic scenarios for risk mitigation. Science of the Total Environment 644, 161-172.

Didoné, E.J, Minella, J.P.G, Evrard, O., 2017. Measuring and modelling soil erosion and sediment yields in a large cultivated catchment under no-till of Southern Brazil. Soil \& Tillage Research 174, 24-33.

Didoné, E.J., Minella, J.P.G., Reichert, J.M., Merten, G.H., Dalbianco, L., Barrros, C.A.P., Ramon, R., 2014. Impact of no-tillage agricultural systems on sediment yield in two large catchments in Southern Brazil. Journal of Soils and Sediments 14, 1287-1297.

Fauvelle, V., Mazzella, N., 2014. Application du POCIS pour l'echantillonnage des pesticides acides dans les eaux de surface : proposition d'une resine echangeuse d'anions comme phase receptrice. Rapport Aquaref - ME-12-Echantillonnage passif des herbicides anioniques. 7p.

GEMEA, 2006. Guideline on the Environmental Risk Assessment of Medicinal Products for Human Use CHMP/SWP/4447/00. The European Agency for theEvaluation of Medicinal Products, London

FEE. FUNDAÇÃO DE ECONOMIA E ESTATÍSTICA. 2019. Indicadores econômicos do agronegócio do Rio Grande do Sul. Disponível em: https://dados.fee.tche.br. Acesso em: 09 de abril de 2019.

Fernandes, G., Aparicio, V.C., Bastos, M.C., Gerónimo, E., Labanowski, J., Prestes, O.D., Zanella, R., Rheinheimer, D.S., 2018. Indiscriminate use of glyphosate impregnates river epilithic biofilms in southern Brazil. Science of the Total Environment 651, 1377-1387. 
Fryirs, K., 2013. Connectivity in catchment sediment cascades: a fresh look at the sediment delivery problem. Earth Surface Processes and Landforms 38, 30-46.

Glusczak, L., Miron, D.S., Moraes, B.S., Simões, R.R., Schetinger, M.R.C., Morsch, V.M., Loro, V.L., 2007. Acute effects of glyphosate herbicide on metabolic and enzymatic parameters of silver catfish (Rhamdia quelen). Comparative Biochemistry and Physiology Part C: Toxicology \& Pharmacology 146(4), 519-524.

Gonzalez-Rey, M., Tapie, N., Menach, K.L.E, Dévier, M.H., Budzinski, H., Bebianno, M.J., 2015. Occurrence of pharmaceutical compounds and pesticides in aquatic systems. Marine Pollution Bulletin 96, 384-400.

Guibal, R., Lissalde, S., Leblanc, J., Cleries, K., Charriau, A., Poulier, G., Mazzella, N., Rebillard, J.P., Brizard, Y., Guibaud, G., 2017. Two sampling strategies for an overview of pesticide contamination in an agriculture-extensive headwater stream. Environmental Science and Pollution Research 25, 14280-14293.

Hair, J.F., Black, W.C., Babin, B.J., Anderson, R.E., Tatham, R.L., 2009. Análise multivariada dos dados. 6rd. ed. Bookman: Porto Alegre, Brasil, 688p.

Harman, C., Allan, I.J., Vermeirssen, E.L.M., 2012. Calibration and use of the polar organic chemical integrative sampler-a critical review. Environmental Toxicology and Chemistry 31, 2724-2738.

Harman, C., Brooks, S., Sundt, R.C., Meier, S., Grung, M., 2011. Field comparison of passive sampling and biological approaches for measuring exposure to PAH and alkylphenols from offshore produced water discharges. Marine Pollution Bulletin 63, 141-148.

Hernando, M.D., Mezcua, M., Fernandez-Alba, A.R., Barcelo, D., 2006. Environmental risk assessment of pharmaceutical residues in wastewater effluents, surface waters and sediments. Talanta $69,334-342$.

Huckins, J.N., Manuweera, G.K., Petty, J.D., Mackay, D., Lebo, J.A., 1993. Lipid-Containing Semipermeable Membrane Devices for Monitoring Organic Contaminants in Water. Environmental Science and Technology 27, 2489-2496.

IBAMA - INSTITUTO BRASILEIRO DO MEIO AMBIENTE E RECURSOS NATURAIS RENOVÁVEIS. 2019. Boletins anuais de produção, importação, exportação e vendas de agrotóxicos no Brasil. $\quad$ Brasília, 2019. Disponível http://www.ibama.gov.br/phocadownload/qualidade_ambiental/relatorios/2014/os_d ez_ias_vendidos_2014.xls. Acesso em: 25 março 2019.

IBGE - INSTITUTO BRASILEIRO DE GEOGRAFIA E ESTATÍSTICA. 2019. Censo Agropecuário 2017. Brasil. Brasília, 2019. Disponível em: https://censos.ibge.gov.br/agro/2017/templates/censo_agro/resultadosagro/agricultur a.html. Acesso em: 25 março 2019.

Ibrahim, I., Togola, A., Gonzalez, C., 2013. Polar organic chemical integrative sampler (POCIS) uptake rates for 17 polar pesticides and degradation products: laboratory calibration. Environmental Science and Pollution Research 20, 3679-3687.

INMET - INSTITUTO NACIONAL DE METEOROLOGIA. Estações Automáticas. Disponível: http://www.inmet.gov.br/portal/index.php?r=home/page\&page=rede_estacoes_auto__ graf. Acesso em: 08 de abril 2019. 
Jablonowski, N.D., Köppchen, S., Hofmann, D., Schäffer, A., Burauel, P., 2009. Persistence of 14Clabeled atrazine and its residues in a field lysimeter soil after 22 years. Environmental Pollution 157(7), 2126-31.

Jeschke, P., Nauen, R., Schindler, M., Elbert, A., 2010. Overview of the Status and Global Strategy for Neonicotinoids (dagger). Journal of Agricultural and Food Chemistry 59(7), 2897-2908.

Kienzler, A., Bopp, S., Halder, M., Embry, M., Worth, A., 2019. Application of new statistical distribution approaches for environmental mixture risk assessment: A case study. Science of the Total Environment 693, 133510.

Koiter, A.J., Lobb, D.A., Owens, P.N., Petticrew, E.L., Tiessen, K.H.D., LI, S., 2013. Investigating the role of connectivity and scale in assessing the sources of sediment in an agricultural watershed in the Canadian prairies using sediment source fingerprinting. Journal of Soils and Sediments 13, 16761691.

Kreutz, L.C., Barcellos, L.J.G., Silva, T.O., Anziliero, D., Martins, D., Lorenson, M., Marteninghe, A., Silva, L.B., 2008. Acute toxicity test of agricultural pesticides on silver catfish (Rhamdia quelen) fingerlings. Ciência Rural 38, 1050-1055.

Lewis, K. A., Tzilivakis, J., Warner, D., Green, A., 2016. An international database for pesticide risk assessments and management. Human and Ecological Risk Assessment: An International Journal 22, $1050-1064$.

Liess M., Schulz, R., Liess, M.H.D., Rother, B., Kreuzig, R., 1999. Determination of insecticide contamination in agricultural headwater streams. Water Research 33, 239-247.

Lissalde, S., Mazzella, N., Mazellier, P., 2014. Polar organic chemical integrative samplers for pesticides monitoring: Impacts of field exposure conditions. Science of the Total Environment 488489, 188-196.

Londero, A.L., Minella, J.P.G., Deuschle, D., Schneider, F.J.A., Boeni, M., Merten, G.H., 2018. Impact of broad-based terraces on water and sediment losses in no-till (paired zero- order) catchments in southern Brazil. Journal of Soils and Sediments 18(3), 1159-1176. Formatted: English (United States)

Loureiro, S., Svendsen, C., Ferreira, A.L.G., Pinheiro, C., Ribeiro, F., Soares, A.M.V.M., 2010. Toxicity of three binary mixtures to Daphnia magna: Comparing chemical modes of action and deviations from conceptual models. Environmental Toxicology and Chemistry 29(8), 1716-1726.

Martínez Bueno, M.J., Herrera, S., Munaron, D., Boillot, C., Fenet, H., Chiron, S., Gomez, E., 2016. POCIS passive samplers as a monitoring tool for pharmaceutical residues and their transformation products in marine environment. Environmental Science and Pollution Research 23(6), 5019-5029.

Masiá, A., Campo, J., Vázquez-Roig, P., Blasco, C., Picó, Y., 2013. Screening of currently used pesticides in water, sediments and biota of the Guadalquivir River Watershed (Spain). Journal of Hazardous Materials 263, 95-104.

Mazzella, N., Dubernet, J.F., Delmas, F., 2007. Determination of kinetic and equilibrium regimes in the operation of polar organic chemical integrative samplers. Journal of Chromatography A 1154(12), 42-51.

Mazzella, N., Lissalde, S., Moreira, S., Delmas, F., Mazellier, P., Huckins, J.N., 2010. Evaluation of the Use of Performance Reference Compounds in an Oasis-HLB Adsorbent Based Passive Sampler for Improving Water Concentration Estimates of Polar Herbicides in Freshwater. Environmental 
Science \& Technology 44(5), 1713-1719.

Merten, G.H., Araújo, A.G., Biscaia, R.C.M., Barbosa, G.M.C., Conte, O., 2015. No-till surface runoff and soil losses in southern Brazil. Soil and Tillage Research 152, 85-93.

Metcalfe, C., Hoque, M.E., Sultana, T., Murray, C., Helm, P., Kleywegt, S., 2014. Monitoring for contaminants of emerging concern in drinking water using POCIS passive samplers. Environmental Science. Processes \& Impacts 16(3), 473-81.

Metcalfe, C.D., Helm, P., Paterson, G., Kaltenecker, G., Murray, C., Nowierski, M., Sultana, T., 2019. Pesticides related to land use in catchments of the Great Lakes basin. Science of the Total Environment 648, 681-692.

Metre, P.C., Alvarez, D.A., Mahler, B.J., Nowell, L., Sandstrom, M., Moran, P., 2016. Complex mixtures of Pesticides in Midwest U.S. streams indicated by POCIS time-integrating samplers. Environmental Pollution 220, 431-440.

Michaelides, K., Chappell, A., 2009. Connectivity as a concept for characterising hydrological behaviour Definitions of Connectivity. Hydrological Processes 522, 517-522.

Michel, N., Freese, M., Brinkmann, M., Pohlmann, J.D., Hollert, H., Kammann, U., Haarich, M., Theobald, N., Gerwinski, W., Rotard, W., Hanel, R., 2016. Fipronil and two of its transformation products in water and European eel from the river Elbe. Science of the Total Environment 568, 171179.

Minella, J.P.G., Walling, D.E., Merten, G.H., 2014. Establishing a sediment budget for a small agricultural catchment in southern Brazil, to support the development of effective sediment management strategies. Journal of Hydrology 519, 2189-2201.

Moreira, J.C., Peres, F., Simões, A.C., Pignati, W.A., Dores, E.C., Vieira, S.N., Strüssmann, C., Mott, T., 2012. Contaminação de águas superficiais e de chuva por agrotóxicos em uma região do estado do Mato Grosso. Ciência \& Saúde Coletiva 17(6), 1557-1568.

Moreira, R.A., Mansano, A.S., Silva, L.C., Rocha, O., 2014. A comparative study of the acute toxicity of the herbicide atrazine to cladocerans Daphnia magna, Ceriodaphnia silvestrii and Macrothrix flabelligera. Acta Limnologica Brasiliensia 26(1), 1-8.

Morin, N., Miège, C., Coquery, M., Randon, J., 2012. Chemical calibration, performance, validation and applications of the polar organic chemical integrative sampler (POCIS) in aquatic environments. Trends in Analytical Chemistry 36, 144-175.

Petty, J., Huckins, J., Alvarez, D., 2002. Device for sequestration and concentration of polar organic chemicals from water. U.S. Patent 6,478,961. U.S. Patent and Trademark Office, Washington, DC.

Petty, J.D., Huckins, J.N., Alvarez, D.A., Brumbaugh, W.G., Cranor, W.L., Gale, R.W., Rastall, A.C., Jones-Lepp, T.L., Leiker, T.J., Rostad, C.E., Furlong, E.T., 2004. A holistic passive integrative sampling approach for assessing the presence and potential impacts of waterborne environmental contaminants. Chemosphere 54(6), 695-705.

Poulier, G., Lissalde, S., Charriau, A., Buzier, R., Delmas, F., Gery, K., Moreira, A., Guibaud, G., Mazzella, N., 2014. Can POCIS be used in Water Framework Directive (2000/60/EC) monitoring networks? A study focusing on pesticides in a French agricultural watershed. Science of the Total Environment 497-498,282-292.

Rabiet, M., Margoum, C., Gouy, V., Carluer, N., Coquery, M., 2010. Assessing pesticide 
concentrations and fluxes in the stream of a small vineyard catchment--effect of sampling frequency. Environmental pollution 158(3), 737-48. REACH (Registration, Evaluation, Authorization and Restriction of Chemicals), 2006. Regulation (EC) No 1907/2006. European Parliament and of the Council. Official Journal of the European Union. L 396/1 to 849.

Rheinheimer, D.S., Pellegrini, A, Alvarez, J.W., Krolow, I.R.C., Capoane, V., Krolow, D.R.V., 2017. Flow Regularization and power dissipation in watershed in the center west region of Rio Grande do Sul state, Brazil. Geociências 36(3), 521-530.

Robinet, J., Minella, J.P.G., Barros, C.A.P., Schlesner, A., Lücke, A., Ameijeiras-Mariño, Y., Opfergelte, S., Vanderborghta, J., Govers, G., 2018. Impacts of forest conversion and agriculture practices on water pathways in Southern Brazil. Hydrological Processes 32(15), 2304-2317.

Sancho, E., Villarroel, M.J., Andreu, E., Ferrando, M.D., 2009. Disturbances in energy metabolism of Daphnia magna after exposure to tebuconazole. Chemosphere 74(9),

Silva, V.S., Poulsen, A., Tjeerdema, R., 2014. The Potential of POCIS and SPMD Passive Samplers to Measure Pesticides in California Surface Waters. Final Report Agreement No. 11-C0115. Department of Environmental Toxicology University of California, 47p.

Sridhar, K., Joice, P.E., 2012. Carbendazim induced histopathological and histochemical changes in liver tissues of common carp Cyprinus carpio. International Journal of Advanced Life Sciences 5(1), 65-70.

Stehle, S., Schulz, R., 2015. Pesticide authorization in the EU-environment unprotected? Environmental Science and Pollution Research 22, 19632-19647.

Stuer-Lauridsen, F., 2005. Review of passive accumulation devices for monitoring organic micropollutants in the aquatic environment. Environmental Pollution 136(3), 503-524.

Terzopoulou, E., Voutsa, D., 2016. Active and passive sampling for the assessment of hydrophilic organic contaminants in a river watershed-ecotoxicological risk assessment. Environmental Science and Pollution Research 23(6), 5577-5591.

Tiecher, T., Minella, J.P.G., Caner, L., Evrard, O., Zafar, M., Capoane, V., Gall, M.L, Rheinheimer, D.S., 2017. Quantifying land use contributions to suspended sediment in a large cultivated catchment of Southern Brazil (Guaporé River, Rio Grande do Sul). Agriculture, Ecosystems \& Environment 237, 95-108.

Toussaint, M.W., Shedd, T.R., van der Schalie, W.H., Leather, G.R., 1995. A comparison of standard acute toxicity tests with rapid-screening toxicity tests. Environmental Toxicology and Chemistry 14(5), 907-915.

Tyor, A.K., Harkrishan, 2016. Effects of imidacloprid on viability and hatchability of embryos of the common carp (Cyprinus carpio L.). International Journal of Fisheries and Aquatic Studies 4(4), 385389.

Vrana, B., Allan, I.J., Greenwood, R., Mills, G.A., Dominiak, E., Svensson, K., Knutsson, J., Morrison, G., 2005. Passive sampling techniques for monitoring pollutants in water. Trends in Analytical Chemistry 24(10), 845-868. 1171-1178.

Schopfer, A., Estoppey, N., Omlin, J., Udrisard, R., Esseiva, P., Alencastro, L.F., 2014. The Use of Passive Samplers to Reveal Industrial and Agricultural Pollution Trends in Swiss Rivers. CHIMIA International Journal for Chemistry 68(11), 778-782. 
Schreiner, V.C., Szöcs, E., Bhowmik, A.K., Vijver, M.G., Schäfer, R.B., 2016. Pesticide mixtures in streams of several European countries and the USA. Science of the Total Environment 573, 680-689.

Scotto, M.A.L., 2014. Fluxos de fósforo em uma bacia hidrográfica sob cultivo intensivo no sul do Brasil. Dissertação (Mestrado em Ciência do Solo) - Universidade Federal de Santa Maria, Santa Maria.

Sequinatto, L., Reichert, J.M., Rheinheimer, D.S., Reinert, D. J., Copetti, A.C.C., 2013. Occurrence of agrochemicals in surface waters of shallow soils and steep slopes cropped to tobacco. Química Nova 36(6), 768-772.

Silva, A.R.R., Cardoso, D.N., Cruz, A., Lourenço, J., Mendo, S., Soares, A.M.V.M., Loureiro, S., 2015. Ecotoxicity and genotoxicity of a binary combination of triclosan and carbendazim to Daphnia magna. Ecotoxicology and Environmental Safety 115, 279-290.

Zhang, W., Jiang, F., Ou, J., 2011. Global pesticide consumption and pollution: with China as a focus. Proceedings of the International Academy of Ecology and Environmental Sciences 1(2), 125-144.

Zeng, H., Xin, F., Liang, Y., Qin, L., Mobc, L., 2018. Risk assessment of an organochlorine Adv. 8(8), 17797-17805. 

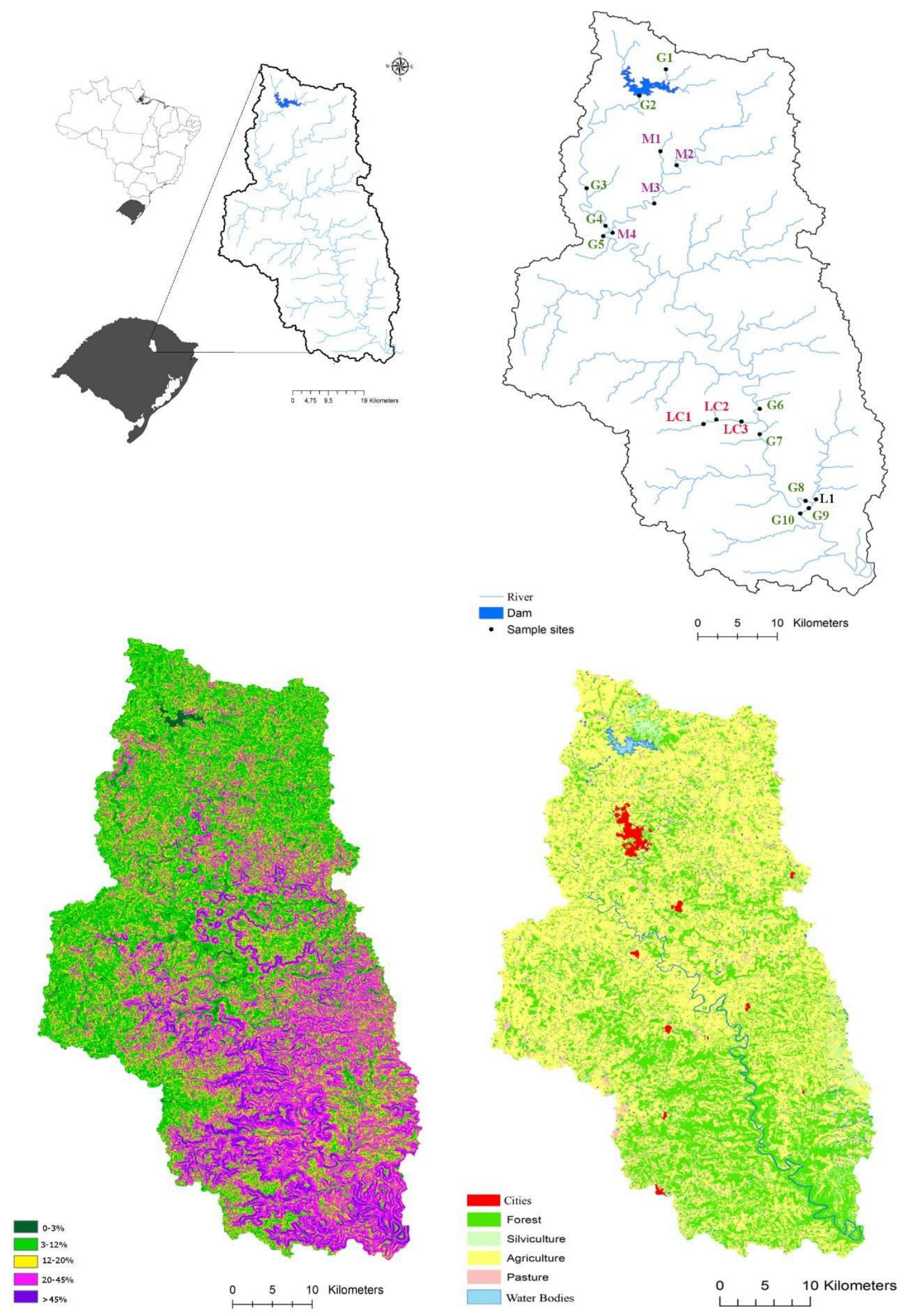

Fig. 1.

Characteristics of area and location of the sampling sites in the Guaporé River and its tributaries (RS - Brazil). 


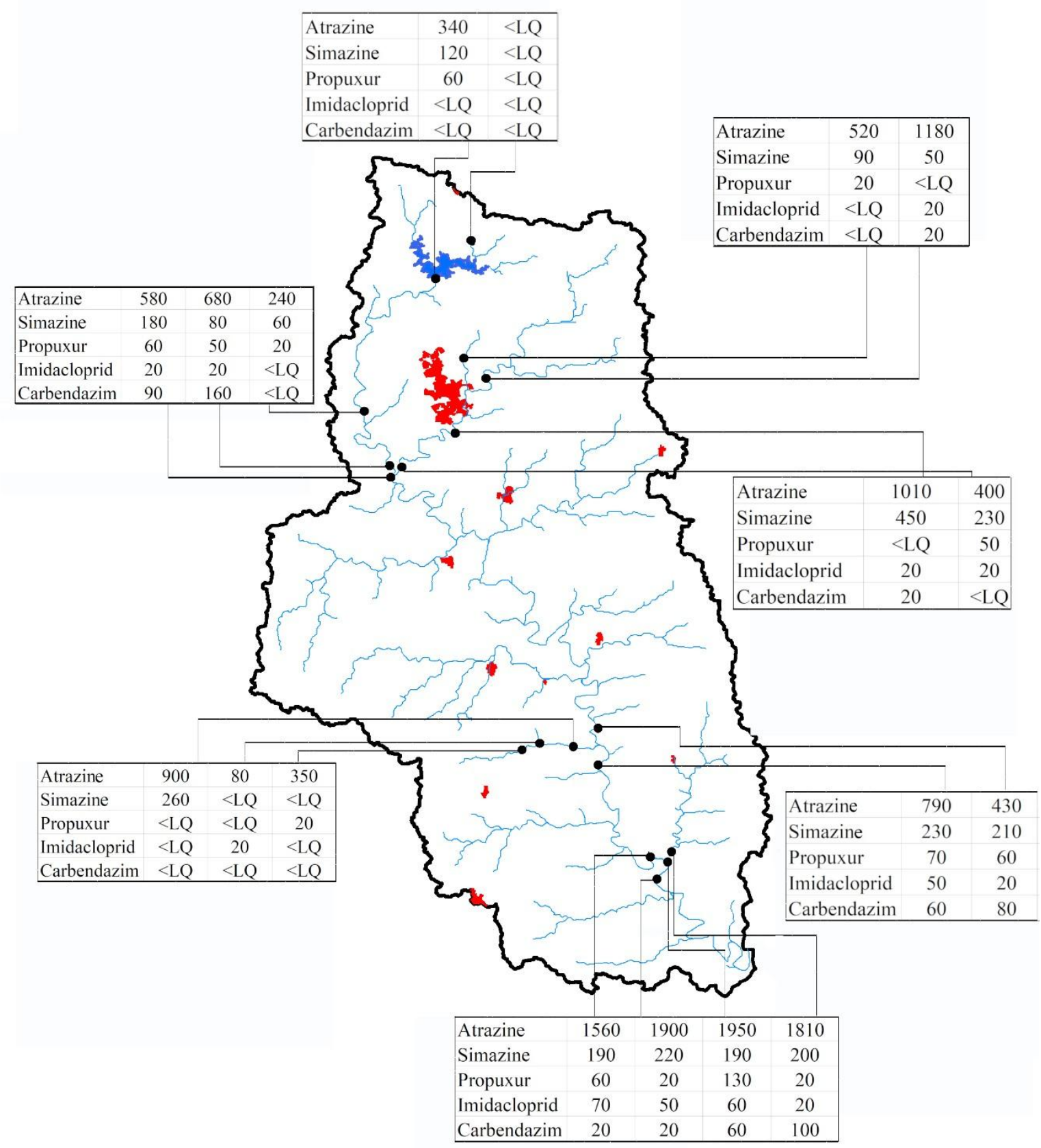

\section{Legend}

- Sample sites

River

Dam

Guaporé Watershed

Cities

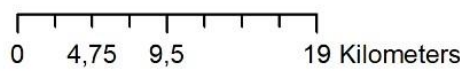

Pesticides concentration ( $\mathrm{ng} \mathrm{L}^{-1}$ ) in Guaporé River and its tributaries, a representative southern Brazilian catchment, obtained by Polar Organic Chemical Integrative Sampler. 


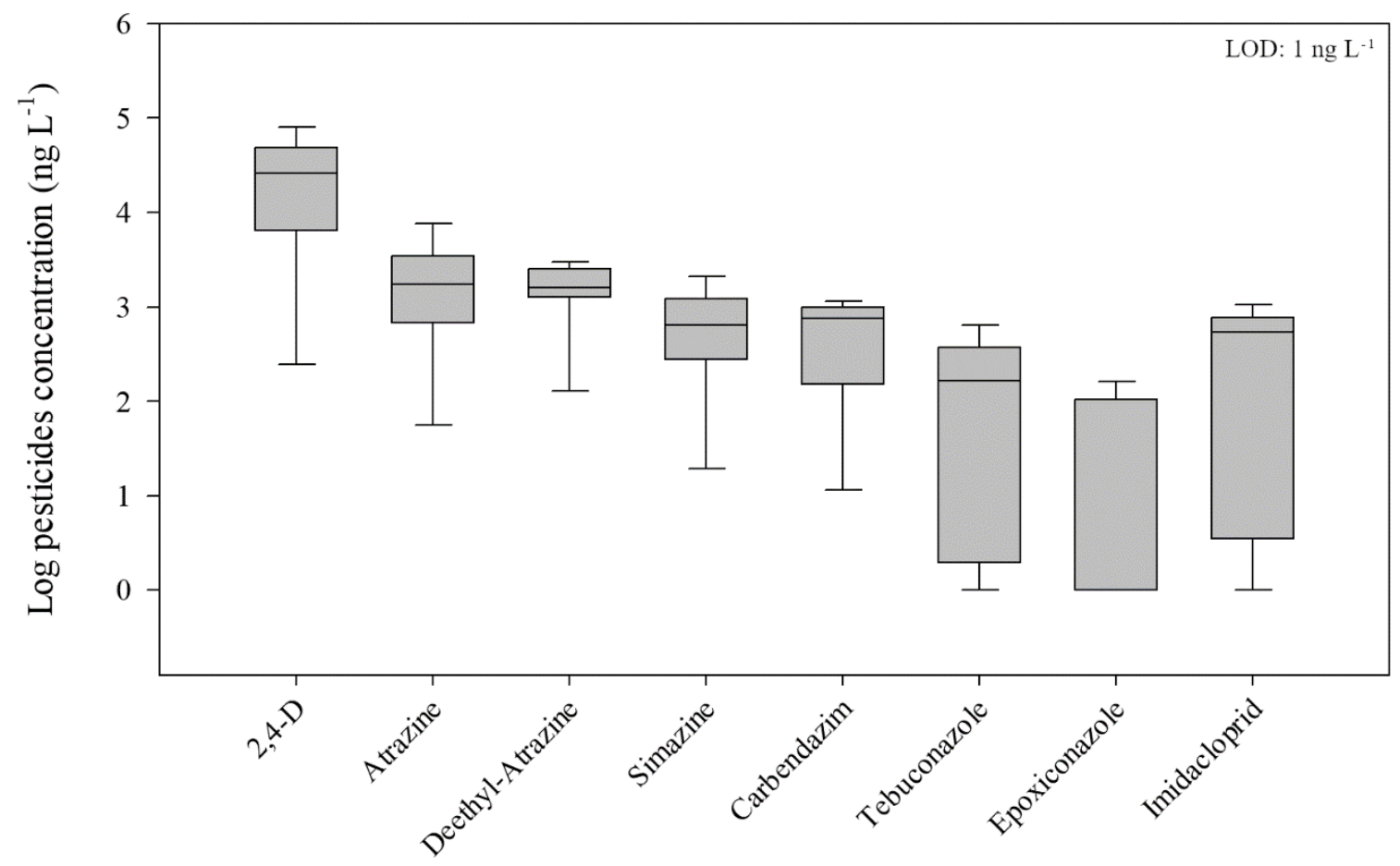

Fig. 4.

Boxplot of the pesticide concentrations detected in the Guaporé River catchment. Median concentrations, interquartile amplitude $\left(1^{\text {st }}\right.$ and $3^{\text {rd }}$ quartile), and minimum and maximum values obtained using POCIS ( $n=16)$. 
2,4 D

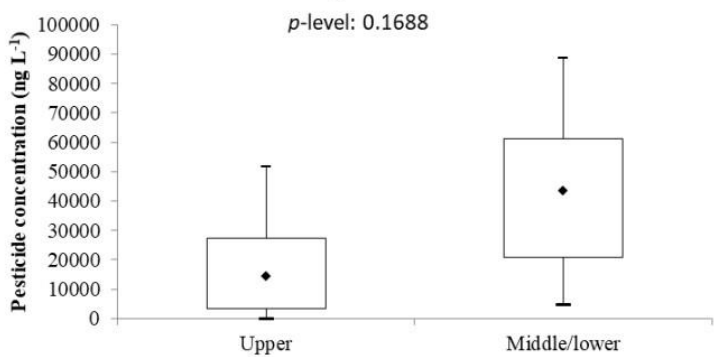

Atrazine

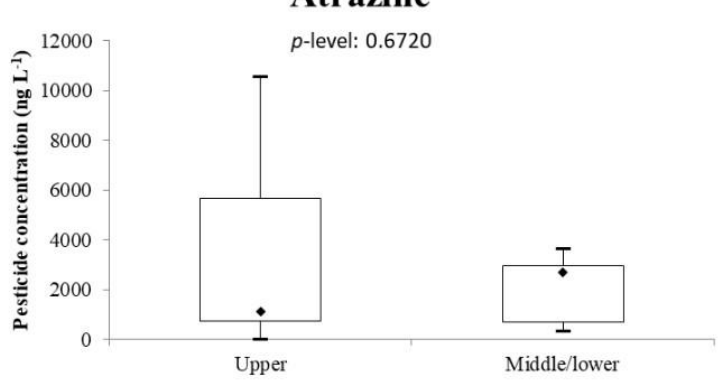

Simazine

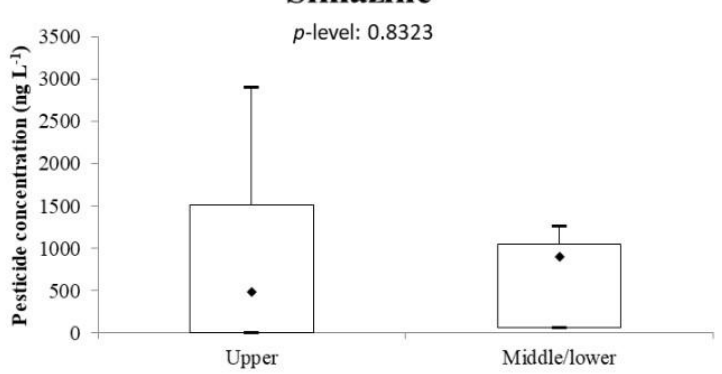

Epoxiconazole

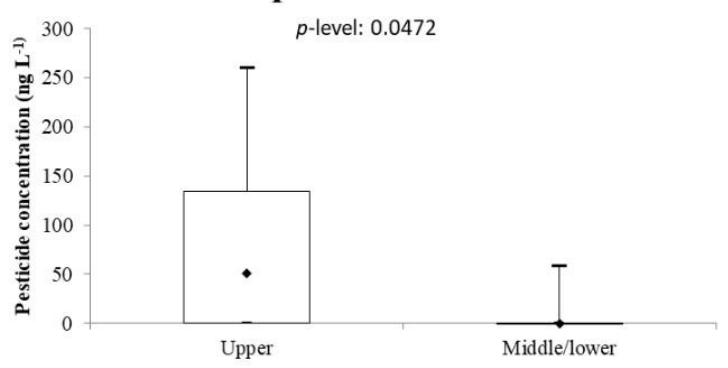

Deethyl-Atrazine

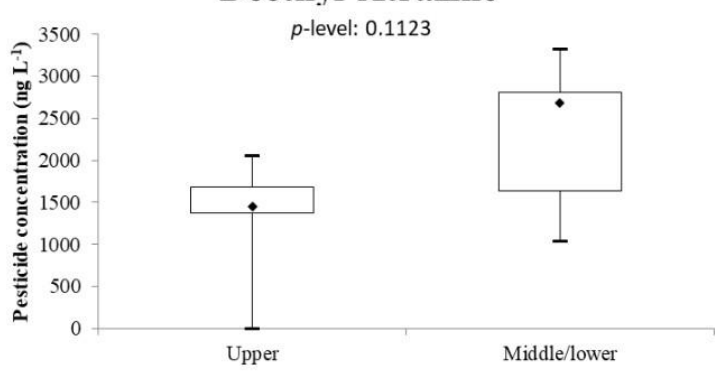

Carbendazim

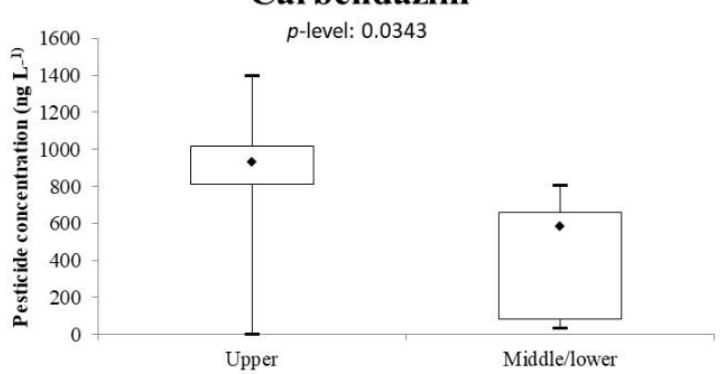

Tebuconazole

p-level: 0.0546

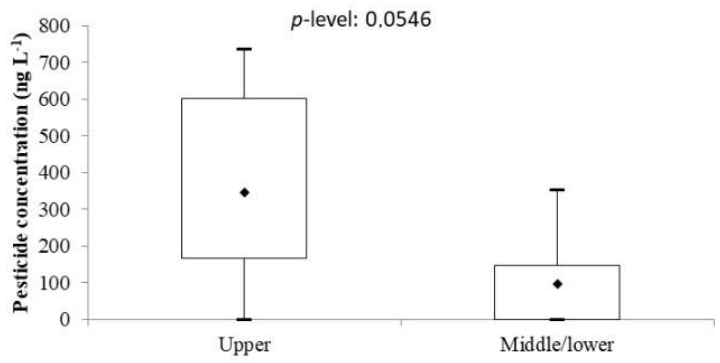

Imidacloprid

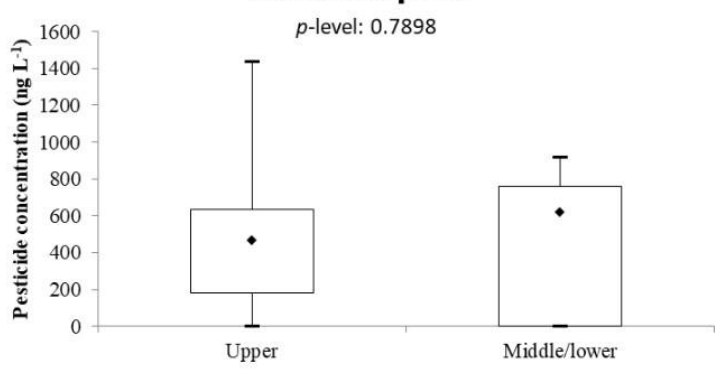

- Median $\square$ 25\%-75\% 工 Min-Max

Fig. 5.

Boxplot of the pesticide concentrations in the two regions of the catchment and results of the Mann-Whitney $U$ test with Polar Organic Chemical Integrative Sampler. 
Table 1

Catchment area, land use and slope class at the different sampling sites in the Guaporé River and its tributaries.

\begin{tabular}{|c|c|c|c|c|c|c|c|c|c|}
\hline \multirow[b]{2}{*}{ Sample sites } & \multicolumn{8}{|c|}{ Upper Region } & \multirow[b]{2}{*}{ M4 } \\
\hline & G1 & G2 & G3 & G4 & G5 & M1 & M2 & M3 & \\
\hline Catchment area $\left(\mathrm{km}^{2}\right)$ & 1.3 & 123 & 201 & 267 & 542 & 13.4 & 165 & 227 & 256 \\
\hline \multirow[t]{2}{*}{ Distance (km) } & 0 & 6 & 23 & 32 & 35 & - & 0 & 10 & 23 \\
\hline & \multicolumn{8}{|c|}{ Land use (\%) } & \\
\hline Forest & 100 & 28 & 24 & 23 & 22 & 22 & 20 & 21 & 22 \\
\hline Agriculture & 0 & 64 & 69 & 71 & 70 & 72 & 74 & 72 & 72 \\
\hline \multirow[t]{2}{*}{ Width riparian forest (m) } & $>800$ & $15-60$ & 15 & 15 & 15 & 15 & 15 & 15 & 15 \\
\hline & \multicolumn{8}{|c|}{ Slope class (\%) } & \\
\hline $0-3 \%$ & 5 & 10 & 9 & 8 & 7 & 6 & 7 & 6 & 6 \\
\hline $3.1-12 \%$ & 49 & 60 & 59 & 58 & 57 & 56 & 60 & 57 & 56 \\
\hline $12.1-20 \%$ & 35 & 22 & 23 & 23 & 24 & 25 & 23 & 24 & 24 \\
\hline $20.1-45 \%$ & 12 & 8 & 9 & 10 & 11 & 13 & 9 & 12 & 13 \\
\hline \multirow[t]{2}{*}{$>45 \%$} & 0 & 0 & 0 & 0 & 1 & 0 & 0 & 1 & 1 \\
\hline & \multicolumn{8}{|c|}{ Middle/Lower Region } & \\
\hline Sample sites & G6 & G7 & G8 & G9 & G10 & LC1 & LC2 & LC3 & $\mathrm{C}$ \\
\hline Catchment area $\left(\mathrm{km}^{2}\right)$ & 1442 & 1505 & 1697 & 1850 & 1853 & 30 & 3.2 & 39 & 144 \\
\hline \multirow[t]{2}{*}{ Distance $(\mathrm{km})$} & 85 & 90 & 106 & 108 & 110 & 0 & - & 3.2 & 0 \\
\hline & \multicolumn{8}{|c|}{ Land use (\%) } & \\
\hline Forest & 27 & 28 & 31 & 32 & 32 & 50 & 61 & 52 & 46 \\
\hline Agriculture & 67 & 66 & 62 & 61 & 61 & 42 & 32 & 40 & 50 \\
\hline \multirow[t]{2}{*}{ Width riparian forest (m) } & 15 & $>60$ & $>100$ & $>100$ & $>100$ & $>100$ & 15 & $>100$ & $>100$ \\
\hline & \multicolumn{8}{|c|}{ Slope class (\%) } & \\
\hline $0-3 \%$ & 6 & 5 & 5 & 5 & 5 & 4 & 1 & 3 & 2 \\
\hline $3.1-12 \%$ & 47 & 45 & 42 & 41 & 41 & 34 & 10 & 28 & 23 \\
\hline $12.1-20 \%$ & 24 & 24 & 23 & 23 & 23 & 24 & 20 & 22 & 27 \\
\hline $20.1-45 \%$ & 21 & 22 & 24 & 26 & 26 & 29 & 53 & 34 & 43 \\
\hline$>45 \%$ & 3 & 4 & 5 & 5 & 5 & 10 & 17 & 14 & 5 \\
\hline
\end{tabular}


Table 2

Frequency of pesticide detection (\%) in Guaporé River and its tributaries using grab and passive (Polar Organic Chemical Integrative Sampler) water sampling

\begin{tabular}{|c|c|c|}
\hline \multirow{2}{*}{ Active ingredient } & \multicolumn{2}{|c|}{ Frequency of detection (\%) } \\
\hline & Grab sampling & POCIS \\
\hline \multicolumn{3}{|l|}{ Herbicides } \\
\hline $2,4-\mathrm{D}$ & 0 & 100 \\
\hline Atrazine & 94 & 100 \\
\hline Deethyl-atrazine & NA & 100 \\
\hline Simazine & 89 & 94 \\
\hline Mesotrione & NA & 31 \\
\hline Thifensulfuron-methyl & NA & 31 \\
\hline Nicosulfuron & NA & 25 \\
\hline Mesosulfuron-methyl & 0 & 19 \\
\hline Prosulfuron & NA & 12 \\
\hline \multicolumn{3}{|l|}{ Fungicide } \\
\hline Carbendazim & 56 & 100 \\
\hline Azoxystrobin & 33 & NA \\
\hline Propiconazole & 17 & NA \\
\hline Tebuconazole & 11 & 75 \\
\hline Epoxiconazole & 0 & 50 \\
\hline \multicolumn{3}{|l|}{ Insecticide } \\
\hline Imidacloprid & 67 & 75 \\
\hline Propoxur & 78 & NA \\
\hline Thiamethoxam & 33 & NA \\
\hline Fipronil & 28 & NA \\
\hline Carbofuran & 6 & NA \\
\hline
\end{tabular}

NA = not analyzed 


\section{Table 3}

Potential ecological risk for Daphinia magnum (M.) and Rhamdia quelen (Teleostei) by pesticides detected in Guaporé River and its tributaries.

\begin{tabular}{|c|c|c|c|c|c|c|}
\hline \multirow{2}{*}{ Site } & \multicolumn{3}{|c|}{ Daphinia magnum (M.) } & \multicolumn{3}{|c|}{ Rhamdia quelen (Teleostei) } \\
\hline & $\mathbf{R Q}_{\text {mix }}$ & 2,4-D & Carbendazim & $\mathbf{R Q}_{\text {mix }}$ & 2,4-D & Carbendazim \\
\hline \multicolumn{7}{|c|}{ Guaporé River } \\
\hline G1 & 0.00 & 0.00 & 0.00 & 0.00 & 0.00 & 0.00 \\
\hline G2 & 179.97 & 1.09 & 177.92 & 138.30 & 136.61 & 0.01 \\
\hline G3 & 206.59 & 2.07 & 203.90 & 260.05 & 258.84 & 0.01 \\
\hline G4 & 188.54 & 1.01 & 187.01 & 127.19 & 126.25 & 0.01 \\
\hline G5 & 212.70 & 2.00 & 210.39 & 251.08 & 250.45 & 0.01 \\
\hline G6 & 164.53 & 3.04 & 161.04 & 381.41 & 380.54 & 0.01 \\
\hline G7 & 144.21 & 3.55 & 140.26 & 444.40 & 443.66 & 0.00 \\
\hline G8 & 125.45 & 1.74 & 123.38 & 218.53 & 217.86 & 0.00 \\
\hline G9 & 117.81 & 0.56 & 116.88 & 72.62 & 71.88 & 0.00 \\
\hline G10 & 93.72 & 0.10 & 93.51 & 13.37 & 13.13 & 0.00 \\
\hline \multicolumn{7}{|c|}{ Marau Tributary } \\
\hline M1 & 163.09 & 0.57 & 162.34 & 71.82 & 71.43 & 0.01 \\
\hline M2 & 279.51 & 0.13 & 279.22 & 16.83 & 16.43 & 0.01 \\
\hline M3 & 202.03 & 0.56 & 201.30 & 72.75 & 72.41 & 0.01 \\
\hline M4 & 11.95 & 0.20 & 11.69 & 24.73 & 24.55 & 0.00 \\
\hline \multicolumn{7}{|c|}{ Lageado Carazinho Tributary } \\
\hline LC1 & 22.77 & 1.84 & 20.78 & 230.59 & 230.27 & 0.00 \\
\hline LC2 & 7.63 & 1.09 & 6.49 & 136.67 & 136.52 & 0.00 \\
\hline LC3 & 22.77 & 1.84 & 20.78 & 230.59 & 230.27 & 0.00 \\
\hline \multicolumn{7}{|c|}{ Carazinho Tributary } \\
\hline L1 & 7.63 & 1.09 & 6.49 & 136.67 & 136.52 & 0.00 \\
\hline
\end{tabular}


Table 4

Mann-Whitney $U$ test for pesticides frequency in upper and middle/lower region in Guaporé River catchment (means and inter-quartile) with active sampling.

\begin{tabular}{lccccccc}
\hline Pesticides & $\begin{array}{c}\Sigma \\
\text { Rank } \\
\text { Upper }\end{array}$ & $\begin{array}{c}\Sigma \\
\text { Rank } \\
\text { Middle/Lower }\end{array}$ & U & Z & $\begin{array}{c}p \text { - } \\
\text { level }\end{array}$ & $\begin{array}{c}\text { Frequency } \\
\text { Upper }\end{array}$ & $\begin{array}{c}\text { Frequency } \\
\text { Middle/Lower }\end{array}$ \\
\hline Atrazine & 59.0 & 94.0 & 23.0 & -1.25093 & 0.2110 & 100 & 100 \\
Simazine & 71.5 & 81.5 & 35.5 & -0.04811 & 0.9616 & 100 & 100 \\
Propoxur & 67.0 & 86.0 & 31.0 & -0.48113 & 0.6304 & 75 & 78 \\
Imidacloprid & 56.5 & 96.5 & 20.5 & -1.49149 & 0.1358 & 62 & 78 \\
Carbendazim & 67.0 & 86.0 & 31.0 & -0.48113 & 0.6304 & 50 & 55 \\
Azoxystrobin & 73.5 & 79.5 & 34.5 & 0.14434 & 0.8852 & 37 & 33 \\
Thiamethoxam & 81.0 & 72.0 & 27.0 & 0.86603 & 0.3865 & 50 & 22 \\
Fipronil & 60.5 & 92.5 & 24.5 & -1.10659 & 0.2685 & 12 & 44 \\
Propiconaloze & 68.5 & 84.5 & 32.5 & -0.33679 & 0.7363 & 12 & 22 \\
Tebuconazole & 64.0 & 89.0 & 28.0 & -0.76980 & 0.4414 & 0 & 22 \\
Carbofuran & 68.0 & 85.0 & 32.0 & -0.38490 & 0.7003 & 0 & 11 \\
\hline
\end{tabular}


Table 5

Results of the discriminant function analysis for regions, upper and middle/lower in Guaporé River catchment.

\begin{tabular}{|c|c|c|c|c|c|c|c|}
\hline Pesticides & Wilks' Lambda & Partial La & mbda & F- Ren & move 1,10 & p-level & $\begin{array}{c}\text { Tolerance } \\
1-\left(\mathbf{R}^{2}\right)\end{array}$ \\
\hline & \multicolumn{7}{|c|}{ Variables in the model $\left(F_{4,10}=19,256\right)$} \\
\hline Carbendazim & 0.600 & 0.192 & & & 2.217 & 0.0001 & 0.8563 \\
\hline Deethil-atrazine & 0.167 & 0.689 & & & 4.527 & 0.0593 & 0.4332 \\
\hline Imidacloprid & 0.217 & 0.529 & & & 8.887 & 0.0138 & 0.8003 \\
\hline \multirow[t]{2}{*}{ 2,4-D } & 0.140 & 0.823 & & & 2.149 & 0.1734 & 0.3367 \\
\hline & \multicolumn{7}{|c|}{ Variables currently not in the model (Df for all F-tests: 1.9 ) } \\
\hline Atrazine & 0.115 & 0.996 & & & 0.028 & 0.870903 & 0.6203 \\
\hline Simazine & 0.114 & 0.992 & & & .067 & 0.802 & 0.6777 \\
\hline Epoxiconazole & 0.114 & 0.996 & & & .030 & 0.867 & 0.7593 \\
\hline \multirow[t]{2}{*}{ Tebuconazole } & 0.114 & 0.997 & & & 0.020 & 0.890 & 0.4954 \\
\hline & \multicolumn{7}{|c|}{ Chi-Square Tests with Successive Roots Removed } \\
\hline Discriminant & Eigenvalue & Cum. Prop & Canor & Roots & Wilks' Lambda & Chi-Sqr. & p-level \\
\hline Function 01 & 7.702 & 1.000 & 0.941 & & 0.115 & 23.800 & $8,8 \times 10^{-5}$ \\
\hline
\end{tabular}


